\title{
Women's Legal Rights and Gender Gaps in Property Ownership in Developing Countries
}

\section{Working Paper}

Author(s):

Gaddis, Isis; Lahoti, Rahul; Swaminathan, Hema

Publication date:

2020-10

Permanent link:

https://doi.org/10.3929/ethz-b-000455402

Rights / license:

Creative Commons Attribution-NonCommercial-ShareAlike 3.0 Unported

Originally published in:

Policy Research Working Paper 9444, https://doi.org/10.1596/1813-9450-9444 


\title{
Policy Research Working Paper 9444
}

\section{Women's Legal Rights and Gender Gaps in Property Ownership in Developing Countries}

\author{
Isis Gaddis \\ Rahul Lahoti \\ Hema Swaminathan
}


Policy Research Working Paper 9444

\begin{abstract}
Women's property ownership matters for their well-being and agency; it can also advance economic prosperity and promote the human development of future generations. Yet, until recently, lack of data has constrained researchers from gaining a comprehensive overview of gender differences in property ownership in the developing world. Using Demographic and Health Survey data from 41 developing countries, this paper seeks to fill this gap, by investigating the extent of gender gaps in the incidence of property ownership (land and housing) and the factors associated with these gaps, focusing on the role of legal systems. The study finds that there is substantial variation in gender gaps across countries, but in almost all countries men are
\end{abstract}

more likely to own property than women. Within countries, gender gaps are most pronounced for groups that are already disadvantaged, that is, the rural population and the poorest quintile. The disadvantage in property ownership experienced by women reflects a variety of factors, including discriminatory norms and laws on inheritance, property ownership, marital regimes, and protection from workplace discrimination. Countries with more gender egalitarian legal regimes generally have higher levels of property ownership by women, especially housing. These results suggest that reforms to establish a more gender-equitable legislative framework could be an important mechanism to increase women's property ownership.

This paper is a product of the Gender Global Theme. It is part of a larger effort by the World Bank to provide open access to its research and make a contribution to development policy discussions around the world. Policy Research Working Papers are also posted on the Web at http://www.worldbank.org/prwp. The authors may be contacted at igaddis@worldbank.org.

The Policy Research Working Paper Series disseminates the findings of work in progress to encourage the exchange of ideas about development issues. An objective of the series is to get the findings out quickly, even if the presentations are less than fully polished. The papers carry the names of the authors and should be cited accordingly. The findings, interpretations, and conclusions expressed in this paper are entirely those of the authors. They do not necessarily represent the views of the International Bank for Reconstruction and Development/World Bank and its affliated organizations, or those of the Executive Directors of the World Bank or the governments they represent.

Produced by the Research Support Team 


\section{Women's Legal Rights and Gender Gaps in Property Ownership in Developing Countries*}

Isis Gaddis

World Bank and IZA

\author{
Rahul Lahoti
}

ETH Zürich

\author{
Hema Swaminathan
}

Indian Institute of

Management Bangalore

JEL: D13, D31, J16, P48

Keywords: Gender gaps, legal discrimination, property ownership, intra-household inequality

\footnotetext{
* The findings, interpretations, and conclusions expressed in this paper are entirely those of the authors. They do not necessarily represent the views of the International Bank for Reconstruction and Development/World Bank and its affiliated organizations, or those of the Executive Directors of the World Bank or the governments they represent. We would like to thank Kathleen Beegle, Bénédicte de la Brière, Markus Goldstein, Caren Grown and Dominique van de Walle for valuable comments on earlier drafts. Of course, all errors are our own. The authors may be contacted at igaddis@,worldbank.org.
} 


\section{Introduction}

In most countries around the world, there are profound differences between men and women in ownership, use and control over assets and wealth. Gender gaps emerge prominently in ownership of land and housing property, which are important assets for the poor in developing countries and the primary means to store wealth in rural communities.

Does it matter if land and housing property and, by extension, overall wealth are disproportionately concentrated in the hands of men? The answer is unambiguously affirmative from a gender equality perspective - women's ownership, use and control over resources matter for their well-being and agency (Grown et al 2005). In addition, a more equitable distribution of property and wealth may advance economic prosperity and promote human development of future generations. This is because gender differences in the ownership of land and other productive assets can induce allocative inefficiencies and foregone economic output (O'Sullivan 2017); and because gender differences in the use of productive resources, and the income derived from them, can affect development outcomes among children (World Bank 2011).

Yet, we do not have an extensive understanding of the extent of gender differences in property ownership or the factors driving these gaps. Household surveys, the primary data source for information on the possession and use of assets, traditionally collect these data for the household as a single unit, thereby obscuring gender differences. Recent efforts, mainly through specialized surveys on individual-level asset data, have started addressing this issue (see Doss et al 2020 for a review). This literature documents sizable gender gaps in asset ownership in developing countries in Africa, Asia and Latin America (e.g. ADB 2017; Deere et al 2013; Jacobs et al 2011; Kes et al 2011; Kilic and Moylan 2016). However, differences in methodology across studies impede broader comparative analysis and limit the conclusions that can be drawn for developing countries at large.

This paper contributes to the emerging literature on gender gaps in property ownership using nationally representative data collected by the Demographic and Health Survey (DHS) program. Recent rounds of the DHS project (starting in 2010) collect data on ownership of land and housing from adult men and women. The DHS is particularly suited for gender analysis of property ownership as eligible respondents are personally asked about their ownership of land and housing property, instead of relying on proxy information given by other household members. Doss et al (2015) use the DHS data to provide estimates of land ownership by women and men for eight countries in Africa. Gaddis et al (2018) expand this analysis to cover 28 African countries.

This research, to the best of our knowledge, is the first to take a global perspective on gender gaps in the ownership of property. Its main contribution is twofold. First, using data from 41 countries across the world, we document the extent of gender gaps in property ownership worldwide and explore descriptive patterns within and across countries. Second, we use multivariate analysis to assess in greater detail what factors are correlated with the gender gap in property ownership, with a particular focus on the role of legal systems. We find that there is substantial variation in gender gaps across countries, but in almost all countries men are more likely to own property than women. Within countries, gender gaps in property ownership are larger for the more disadvantaged population groups - that is, they are larger in rural than in urban areas, and larger for the poorest than for the richest wealth quintiles. But what drives these gender gaps? While the analysis in this paper cannot establish causality, the multivariate analysis shows that women's disadvantage in property ownership is associated with discriminatory norms and laws 
with respect to inheritance, property ownership, marital regimes and protection from workplace discrimination. Countries with more gender egalitarian legal regimes generally have higher levels of property ownership by women. The relationship between the legislations and women's property ownership holds across rural and urban areas and is much stronger for housing than land ownership. These results suggest that gender-equitable legislative reforms could be an important avenue to increase women's property ownership.

This paper proceeds as follows. Section 2 discusses the importance of women's ownership of immovable property and the pathways through which women typically acquire such ownership, focusing on the role of legal systems. Section 3 describes the DHS data and shows descriptive patterns of gender gaps in property ownership across and within countries. Section 4 uses multivariate regression techniques to explore how laws with respect to inheritance, property ownership, marital regimes and protection from workplace discrimination are associated with women's ownership of land and housing in developing countries. Section 5 concludes.

\section{Women and Property}

\subsection{The importance of women's property ownership}

There is significant evidence that women's rights to property and other assets are associated with improved well-being and agency. Many models of household behavior, such as cooperative bargaining models proposed by Manser and Brown (1980) and McElroy and Horney (1981), predict that bargaining power within the marriage depends on the husband's and wife's 'outside options', e.g. their expected utility if the union were to end. These outside options depend, among other factors, on who in the family owns the household's property, and the rules and norms that shape the division of assets and other family resources upon divorce (Lundberg and Pollak 1996; Lundberg et al 1997; Fafchamps and Quisumbing 2005). Empirical studies suggest that a more egalitarian distribution of assets between husband and wife, or the wife's property ownership directly, correlate with the wife's participation in intrahousehold decision making (e.g. Beegle et al 2001 for Indonesia; Oduro et al 2012 for Ghana; Swaminathan et al 2012 for India; Mishra and Sam 2016 for Nepal; Behrman 2017 for Malawi); decision-making being considered an indicator of agency (Kabeer 1999). Property ownership or wealth can also offer protection from intimate partner violence for women (Panda and Agarwal 2005; Oduro et al 2015). Studies from India show that legislative changes under the Hindu Succession Act, which strengthened women's inheritance rights, positively impacted measures of female empowerment (i.e. education and health outcomes). These effects were even larger for the 'second generation', i.e. daughters born to women themselves affected by the reforms (Deininger et al 2013, 2018; Roy 2015).

In addition to positively impacting women's own well-being and agency, property ownership can have implications for children's outcomes. As discussed in World Bank (2011), many studies find that an increase in women's control over the household's resources leads to increased spending on food (e.g. Duflo and Udry 2004 for Côte d'Ivoire; Doss 2005 for Ghana), greater investment in health, education and children's goods (e.g. Thomas 1997 for Brazil; Quisumbing and de la Brière 2000 for Bangladesh) and improvements in development outcomes and well-being 
among children (e.g. Thomas 1990 for Brazil; Allendorf 2007 for Nepal; Qian 2008 for China; Luke and Munshi 2011 for India; Menon et al 2014 for Vietnam). ${ }^{1}$

Finally, lack of ownership of land and other productive assets by women can lead to inefficiencies. Goldstein and Udry (2008) show that Ghanaian women underinvest in soil fertility due to tenure insecurity, which causes a loss of output for the household as a whole. Dillon and Voena (2017) find that, in communities with weak inheritance rights for widows, concerns over eviction deter land investments even among currently married women. These microeconomic inefficiencies may be exacerbated if gender gaps in the ownership of land and other immovable property, due to their dual function as collateral, reinforce gender gaps in access to credit and other productive inputs (World Bank 2011).

\subsection{Women's pathways to property ownership}

This section discusses several pathways through which women obtain ownership of land and housing property, and the constraints they encounter relative to men. We focus on life events, particularly marriage and inheritance, which, in most developing countries, are the principal channels for both women and men to acquire property. For example, the Gender Asset Gap project shows that most agricultural parcels are inherited in Ecuador (53 percent), Ghana (59 percent) and Karnataka, India (86 percent). Similarly, between 34 percent (Karnataka) and 45 percent (Ghana) of all housing lots and between 8 percent (Ecuador) and 57 percent (Karnataka) of principal residences are received as inheritances. Besides life events, the section also discusses, although in less detail, other channels through which individuals obtain property - principally purchases. Within each pathway, gender gaps can emerge from an interaction between households, markets and social norms or institutions (World Bank 2011).

We begin with the first pathway, marriage, by reviewing how basic institutional rights to property ownership sometimes change for women upon marriage. According to the 2020 Women, Business and the Law (WBL) database, married women face legal restrictions on property ownership in 19 out of 190 countries for which data are available. While property rights of unmarried women are no longer included as a separate indicator in the $2020 \mathrm{WBL}$, earlier versions of the data showed that unmarried women typically have the same rights as unmarried men (Gaddis et al 2018). This demonstrates that, from a legal perspective, discriminatory provisions often do not apply to all women but to married women specifically, whose legal status changes, sometimes profoundly, upon marriage (Hallward-Driemeier and Hasan 2013).

Today's property rights of women in marriage often have historical roots. British common law was particularly unfavorable to women, owing to the doctrine of 'couverture', whereby a woman's legal status was subsumed by her husband upon marriage. Roman and Islamic legal traditions generally allowed married women to retain their legal personality (Deere and Doss 2006). Nowadays, women's and men's ability to own property during marriage and after its dissolution is governed by marital property regimes and other laws specifying how nonmonetary contributions to the marriage - for example, childcare or other unpaid domestic work from a stay-at-home spouse - are taken into consideration for the distribution of property between spouses. The most common

\footnotetext{
${ }^{1}$ Some studies do not support this notion. Akresh et al (2016) find that (conditional) cash transfers given to women in rural Burkina Faso improve routine health checkups of children by a similar magnitude as transfers given to men.
} 
marital regimes are full community of property, which considers all assets as joint property of the couple, partial community of property, which considers assets acquired during the marriage as joint property but allows spouses to retain assets brought into the marriage, and separation of property, where all property is individually owned. ${ }^{2}$ Overall, women are expected to fare better under community property regimes, which recognize women's role in the accumulation of marital property through child-rearing and other unpaid work, than under separation of property regimes, which reinforce gender gaps in economic and labor market opportunities (Deere and Doss 2006; Deere et al 2013). Figure 1 shows for each country whether the law provides for the valuation of nonmonetary contributions (see Table A1, Appendix for data definitions). ${ }^{3}$ While many countries recognize non-monetary contributions to the marriage, gaps remain in as many as 30 percent of the countries largely concentrated in the Middle East and North Africa, South Asia and SubSaharan Africa. ${ }^{4}$

Figure 1: Legal recognition of nonmonetary contributions to marital property

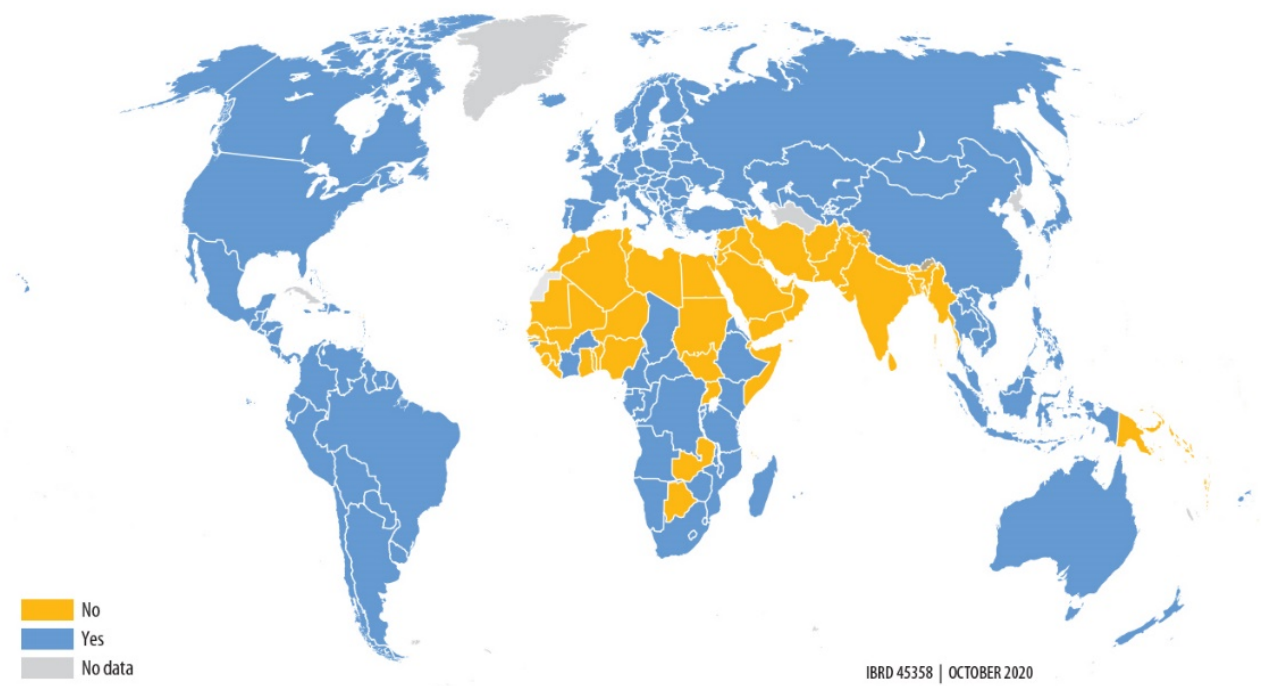

Note: 'Yes' denotes that the country's laws explicitly recognize nonmonetary contributions and/or that the marital property regime is full, partial or deferred community. Source: WBL 2020.

\footnotetext{
2 A special case is 'deferred community of property regimes', in which the separation of property applies until the marriage is dissolved, when the rules of full or partial community of property come into effect (World Bank 2015).

${ }^{3}$ As described in World Bank (2020a), the indicator is coded affirmatively if there is an explicit legal recognition of nonmonetary contributions (and the law provides for equal or equitable division of the property or the transfer of a lump sum to the stay-at-home spouse) or if the default marital property regime is full, partial or deferred community (because, as discussed above, these regimes implicitly recognize nonmonetary contributions at the time of property division). This indicator, which was newly introduced in 2020 , therefore combines the marital regime with other laws regulating nonmonetary contributions, which makes it more difficult to interpret than the previous WBL indicator that considered only the marital regime.

${ }^{4}$ While this paper emphasizes laws that govern married women's property rights, marriage itself often involves interfamilial transfers, which can be broadly categorized as bride price (from the groom's family to that of the bride's; most common in parts of Africa and East Asia) or dowry (from the bride's family to the bride and her groom; most common in South Asia). To our knowledge, little is known how these interfamilial transfers affect property ownership of men and women, though it seems that movable assets (such as livestock, cash or consumer goods) are more commonly transferred than immovable property (for bride prices: see Goldschmidt 1974; Ansell 2001; Dekker and Hoogeveen 2002; Anderson 2007; Corno and Voena 2016; Hudson and Matfess 2017; for dowries: see Harrell and Dickey 1985; Anderson 2007; Maitra 2007; Arunachalam and Logan 2008; Bhalotra et al 2020a).
} 
A life event that is even more salient than marriage for property acquisition is inheritance. Statutory inheritance laws contain several provisions that play a role for gender gaps in property ownership, such as stipulations regarding the partibility of inheritance and the degree of testamentary freedom. They also interact with marital regimes - for example, inheritance rights for widows are particularly relevant under the separation of property regimes, where women cannot automatically claim ownership of their deceased husband's estate (Deere and Doss 2006; Hallward-Driemeier and Hasan 2013). Figure 2 displays two key aspects of inheritance regimes the extent to which the legal code provides for equal treatment of sons and daughters (Figure 2a) and of male and female surviving spouses (Figure $2 b$ ). About 23 percent of countries discriminate on each of these aspects, with a strong overlap in countries that discriminate with respect to both, children and spouses. These countries are largely in the Middle East and North Africa, in parts of Sub-Saharan African as well as South and South East Asia.

Figure 2a: Inheritance rights of children

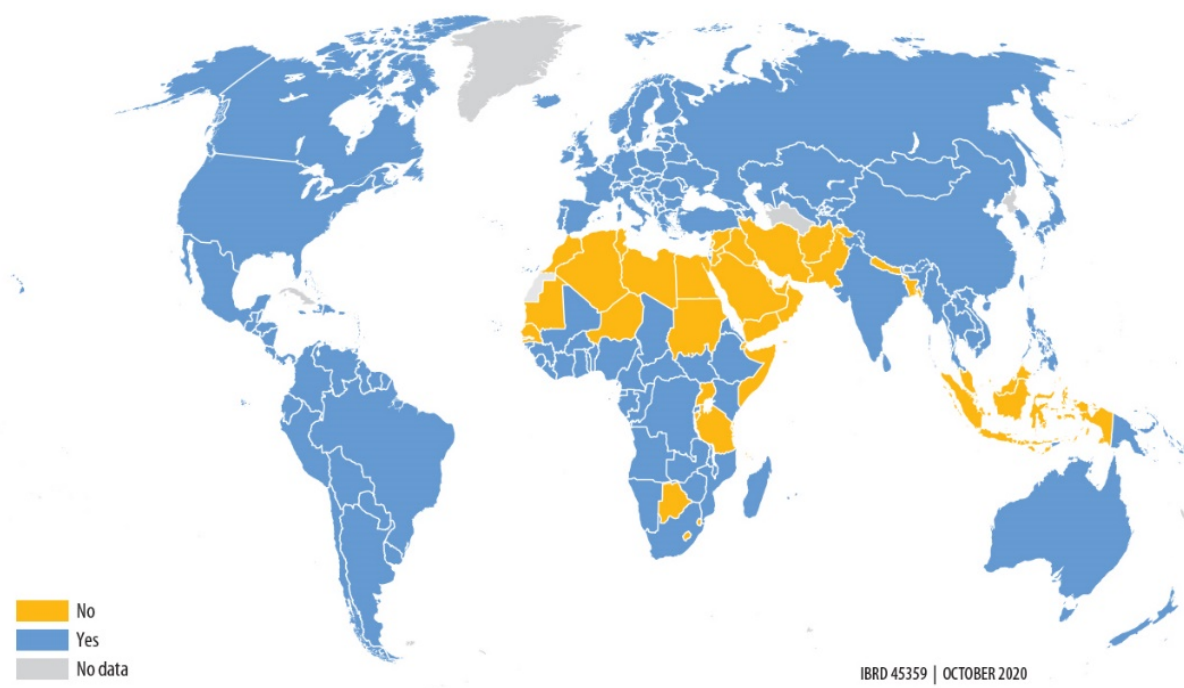

Figure 2b: Inheritance rights of spouses

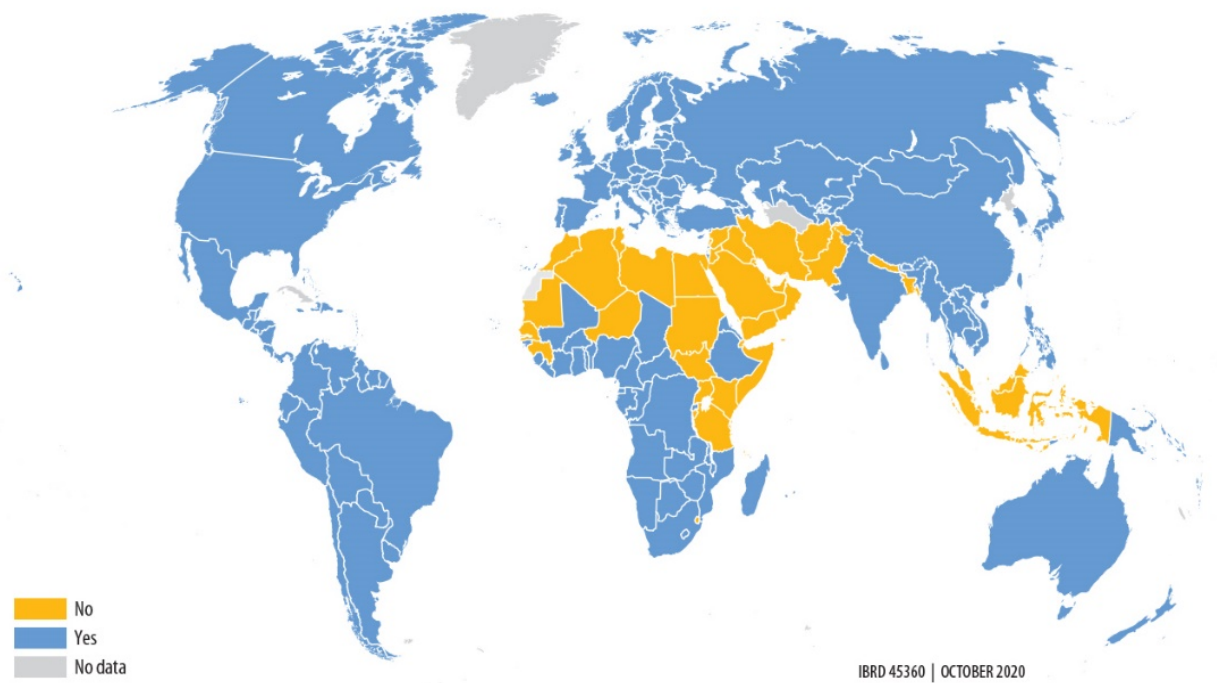

Note: 'Yes' denotes that the country's laws provide for equal treatment of male and female children and male and female surviving spouses, respectively. Source: WBL 2020. 
Finally, women may be disadvantaged in market-based forms of property acquisition, primarily due to gender gaps in economic opportunities and earnings. In most countries, fewer women than men are in the labor force, and when they do work, they tend to be disproportionately engaged in less profitable sectors and occupations and achieve lower levels of earnings (World Bank 2011). Even in the situation of formal sector employment, women may be disadvantaged due to pervasive gender wage gaps across countries. Given the importance of earnings for property acquisition, we consider if countries have any law that mandates equal remuneration for work of equal value (Figure 3), which is one of the legal mechanisms to address gender pay gaps. More than half the countries (about 54 percent) do not explicitly disallow gender discrimination in pay; these are mainly all countries in South Asia, a majority in South East Asia, and a smattering in Sub-Saharan Africa and South America. In comparison (not shown), laws prohibiting discrimination in employment based on gender are much more widespread. Only 19 percent of countries do not have a law against such discrimination.

Figure 3: Protection from discrimination in pay

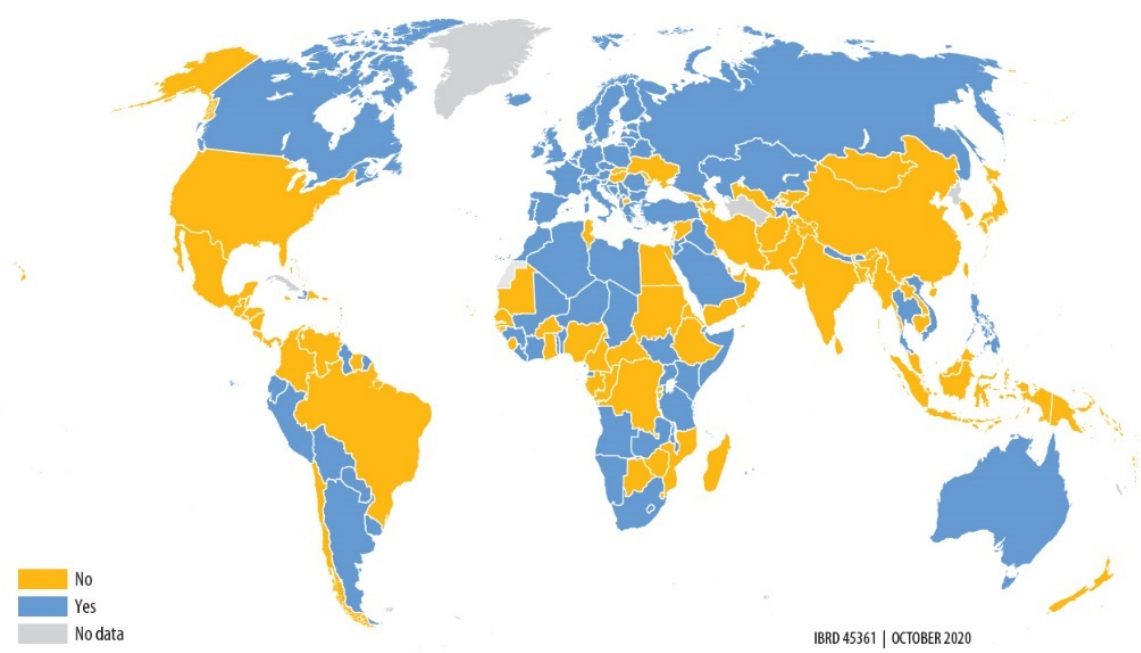

Note: 'Yes' denotes that the law mandates equal remuneration of women and men for work of equal value. Source: WBL 2020.

Even in countries with laws that prohibit gender-based discrimination in employment and remuneration there are many factors that, singly or in combination, can lead to gender gaps in economic opportunities. These factors include gender differences in access to productive resources (e.g. land and other property, capital and labor) and investment security (Goldstein and Udry 2008; O'Sullivan et al 2014), organizational practices (Bertrand 2020) or sticky social norms (Alesina et al 2013; Gaddis and Klasen 2014; Giuliano 2017; Klasen 2019; Jayachandran 2020). As a result, women typically earn and control a smaller share of household income than men and are hence, disadvantaged in accumulating savings for property investment. Moreover, women may face disproportionate barriers in access to financial products commonly used to finance land and housing acquisitions, especially savings accounts and mortgages (Demirgüç-Kunt et al 2018) and may face discrimination in property markets due to lack of bargaining power (Deere and Leon 2003). Even in those developing countries where most property is currently acquired through inheritance; these factors may assume greater importance in the future as property markets come into play through better secured property rights. 


\section{Descriptive patterns of gender gaps in the ownership of land and housing}

\subsection{DHS data on women's and men's property ownership}

Most household surveys gather data on the asset and property ownership for the household as a whole ("does this household own any...") from a single respondent, often the person deemed to be the 'most knowledgeable household member' or the 'head of the household'. However, to assess gender gaps in ownership it is necessary to have data on which individuals within the household own the asset (Kilic and Moylan 2016).

One of the few survey programs that provide data on individual-level property ownership for developing countries across different regions is the DHS, where surveys conducted under the $6^{\text {th }}$ phase or later (from approximately 2010 onwards) typically include the questions (a) "do you own any land either alone or jointly with someone else?" and (b) "do you own this or any other house either alone or jointly with someone else?" in the women's and men's questionnaires. And unlike many other surveys, the DHS protocols do not use proxy respondents but interview husbands and wives separately from each other and in private (ICF International 2012). Asking individuals directly about their ownership rights over assets is generally assumed to best capture their personal perceptions and avoid biases from proxy respondents (Doss et al 2020). Based on a review of DHS questionnaires, we identified 41 countries with data on women's and men's property ownership (see Table A2, Appendix). ${ }^{5}$

Besides these advantages, it is important to acknowledge that there are dimensions of property ownership on which the DHS data cannot provide answers. First, the DHS data only capture the incidence of men and women owning any land and/or housing, and do not provide information on the monetary value of these assets. Second, ownership itself is a complicated context in societies shaped by legal pluralism and informal claims to the property. As discussed in Schlager and Ostrom (1992), property rights can be described along a continuum, which ranges from authorized user to claimant, proprietor and ultimately owner. In this spirit, Kilic and Moylan (2016) distinguish between reported owners, economic owners, documented owners and holder of various bundles of rights. These differing ownership and use rights do not necessarily fall together (Slavchevska et al 2017; Doss et al 2020). ${ }^{6}$ The DHS questions that were added to the $6^{\text {th }}$ round, capture a concept closest to that of reported ownership but cannot distinguish between different forms of ownership or provide information about the security of ownership. ${ }^{7}$ Moreover, even though the DHS are fairly standardized, regional differences in tenure systems may affect the interpretation of questions about individual ownership. Likewise, because the DHS data ask about land and housing in general and do not refer to specific assets (e.g. a specific parcel of land, or a

\footnotetext{
5 The DHSs for South Africa and Liberia collected data only on housing ownership, but the countries are still included in the analysis. We do not include data sets that collect data on women's (but not men's) property ownership, or vice versa. In countries where data on women's and men's property ownership are available from multiple DHS rounds, only the most recent survey is used. Data sets released after June 18, 2020 are not considered.

${ }^{6}$ For example, in many parts of Africa, village chiefs, kinship groups and extended families may engage in specific aspects of property transactions (Pande and Udry 2005; Doss et al 2015). Based on data for Senegal, Lambert et al (2014) show that even though 17 percent of women inherited some land from their parents, only 2 percent have land to bequest to their heirs, suggesting that women's land ownership rights are often revocable.

${ }^{7}$ DHSs conducted under the $7^{\text {th }}$ and $8^{\text {th }}$ rounds collected additional information on the availability of title deeds. However, these data are not yet available for a large cross-section of countries.
} 
specific residential unit), they do not allow 'reconciling' intra-household discrepancies in perceptions about ownership (see Doss et al 2020 for a discussion).

This paper reports on two different concepts of reported ownership, depending on whether a respondent owns property alone or jointly with someone else, typically (but not always) his/her spouse. The DHS questions on individual property ownership provide four response categories (1) "alone only", (2) "jointly only", (3) "both alone and jointly", and (4) "does not own". In the analysis, the category 'sole ownership' combines options (1) and (3), while the category 'sole and joint' combines options (1), (2) and (3). Joint ownership of property is a common occurrence in many of the countries included in this study, and gender gaps are generally smaller than in sole ownership. There are reasons to expect that joint ownership rights may be weaker than individual ownership rights. Joint property ownership does not necessarily mean that men and women have equal rights; women may be disadvantaged in decision-making when their interests do not align with those of their husbands (Agarwal 2003; Doss et al 2014; Jacobs and Kes 2015). On the other hand, joint ownership may be preferable in contexts where women face high social cost in obtaining sole ownership rights (Jackson 2003). There is also no clear policy path for advancing sole property ownership for married men and women, given that housing property is typically nonpartible, while land property is partible only to a certain degree due to concerns around land fragmentation. Given these considerations, the main indicator used in this paper is the sole and joint ownership combined. However, sole ownership is often reported separately, where this is thought to provide further insights. In the interest of parsimony, land and housing ownership is in some analyses combined into a single indicator of property ownership, which equals unity if a woman or man owns land and/or housing, and zero otherwise.

Our analysis is based on the DHS's 'couple sample', that is men and women who were both interviewed, lived in the same household and named each other as a spouse. This excludes households where a married couple was not interviewed because there was no married couple in the household or for other reasons. It also excludes unmarried individuals living in households with a principal couple included in the analysis. Comparing husbands and wives allows us to focus on the intra-household property allocation, whilst abstracting from gender differences in marital status and other demographic factors.

The descriptive analysis focuses on the absolute gender gap, that is the percentage point difference between the share of men and women who report owning property. The drawback here is that absolute gaps do not provide information on the incidence of male and female property ownership, that is how high or low ownership rates may be. However, more detailed statistics on land and housing ownership at the country-level are reported in Table A3 (Appendix). ${ }^{8}$

\footnotetext{
${ }^{8}$ For example, two countries with the same absolute gender gap in property ownership (say 10 percentage points) may have different shares of men and women owning property (say 20 and 10 percent in country A vs. 70 and 80 percent in country B). The alternative would be to report relative gender gaps, which are measured as the percent difference in the incidence of property ownership between men and women. Thus, relative gender gaps are larger in country A, where men are twice as likely to own property than women, compared with country B, where male ownership is just 14 percent higher than female ownership. However, relative gender gaps can be imprecisely estimated in cases where female ownership is low and are - as the percent difference of an indicator itself reported in percent - somewhat less intuitive.
} 


\subsection{Patterns across countries}

Women's disadvantaged position is widespread and systematic. Figure 4 shows the percentage point difference between men and women in the incidence of land and housing ownership at the country level (a positive value indicating that more men than women own the asset). In all but one country (the Comoros), women are less likely than men to claim sole as well as sole and joint ownership over land and housing. For most countries, gender gaps in the ownership of land are greater than in the ownership of housing. Gender gaps are more nuanced if one combines sole and joint ownership (panel b). But even if joint ownership is taken into consideration, men are considerably more likely to own land and housing in most countries included in our analysis.

The largest gender gaps in property ownership are found in Sub-Saharan Africa, especially West Africa (see Figure 4). However, there is large variation between African countries, with gender gaps being much smaller in Southern Africa than in other parts of the continent. Outside of Africa, gender gaps are also sizeable in South Asia, Europe and Central Asia and the Middle East and North Africa (though the latter is based on just one country, Jordan). They are much smaller in East Asia and the Pacific and in Latin America and the Caribbean.

Are gender gaps in property ownership smaller in countries with higher levels of income? Perhaps surprisingly, there is only a weak negative correlation between log GDP per capita and the gender gap in property ownership (with a bivariate correlation coefficient of -0.33) at least for the levels of income found in this sample of countries. ${ }^{9}$ This is consistent with the observation that, across Africa, the legal and economic rights of women are not strongly linked to income (Hallward-Driemeier and Hasan 2013). It suggests that economic growth in isolation may not necessarily reduce gender inequalities (Klasen 2020).

The results also show that, at least at the country level, gender gaps in the ownership of land and housing often go together. The bivariate correlation between the (absolute) gender gap in sole ownership of land and housing across countries is 0.95 ; it is 0.93 for the sole and joint ownership combined. In other words, in countries where women are less likely than men to own land, they are also less likely than men to own housing, and vice versa. One explanation is that in rural areas land and housing is often a considered as a combined asset (Kes et al 2011). Another one is that acquisitions of both assets are governed by similar formal and informal laws, regulations and norms. In the remainder of this section we collapse information on both variables into a single indicator of property ownership, which equals unity if a woman or man owns the land and/or housing (the sole vs. joint ownership distinction is maintained).

\footnotetext{
${ }^{9}$ In our sample, 2015 GDP per capita varies between \$228 (Burundi) and \$7,572 (Colombia), measured in constant 2010 US\$.
} 


\section{Figure 4: Gender gaps in land and housing ownership among married couples}

(a) Sole ownership

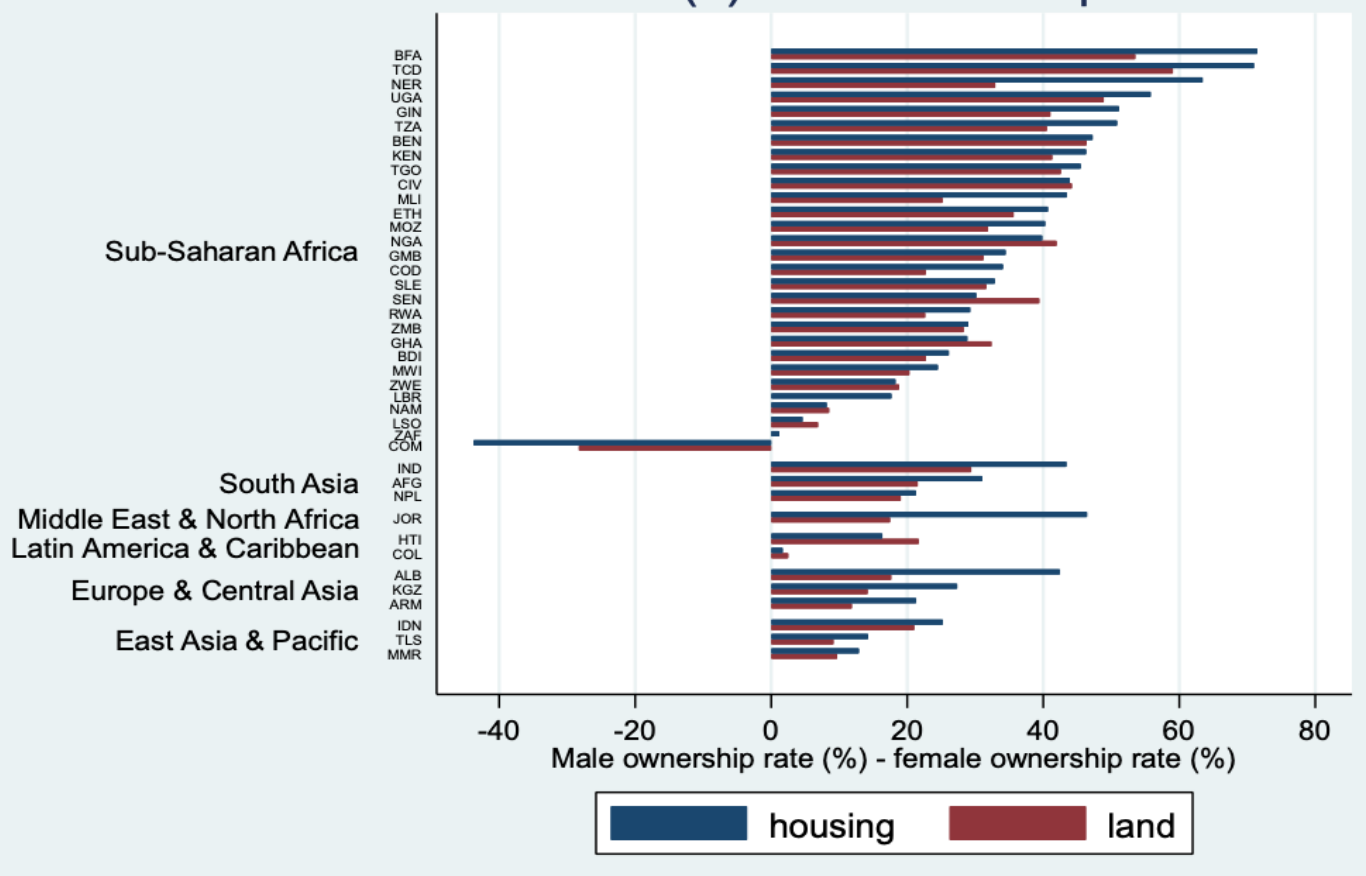

(b) Sole and joint ownership

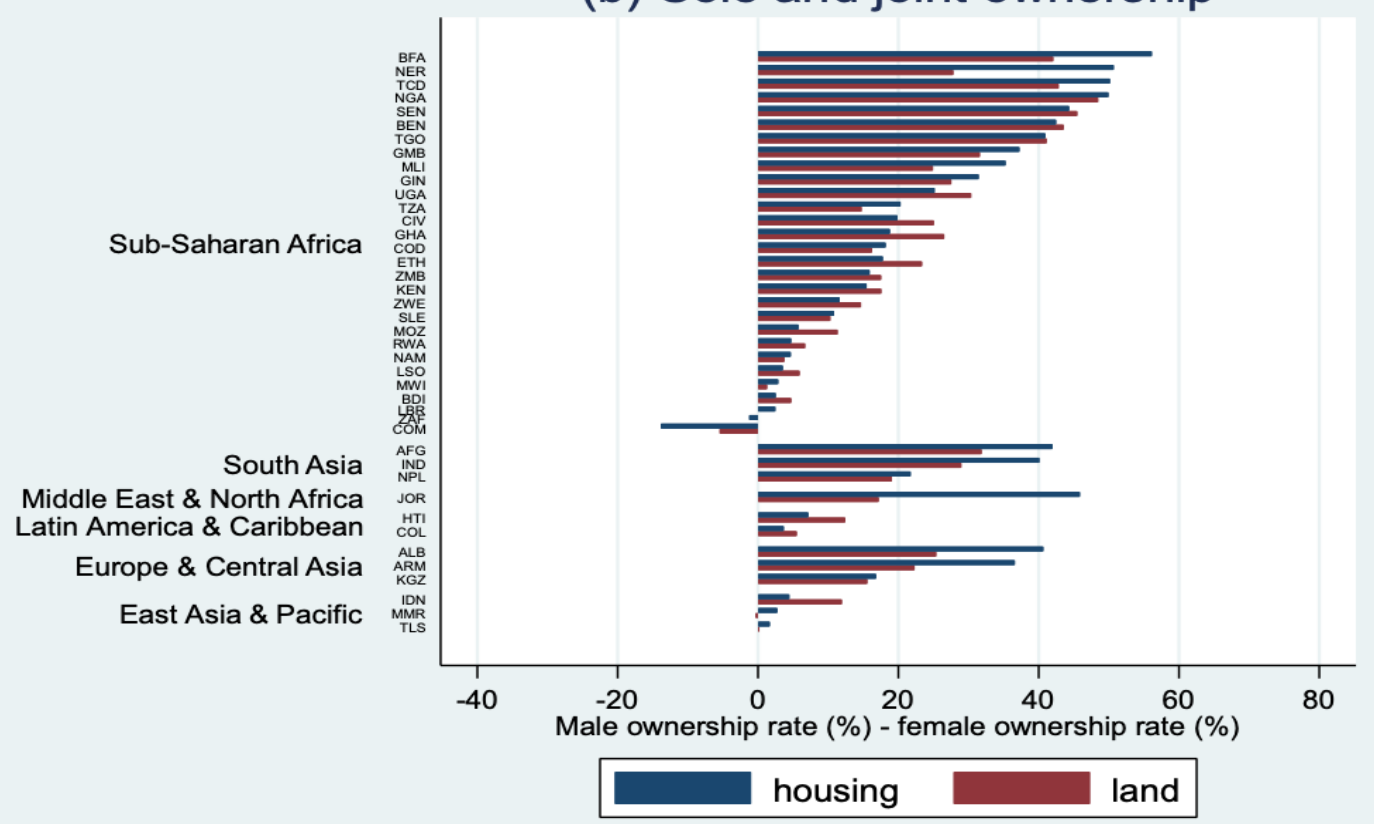

Note: Data for 41 countries from 2010-18. South Africa and Liberia only have data on housing ownership. Based on DHS couples recode (i.e. married couples). Source: DHS. 


\subsection{Patterns within countries}

How are gender gaps shaped by urbanization? Though we lack panel data or repeated crosssections to explore trends over time, we can compare gender gaps between urban and rural areas. Own land has a central role in rural areas, as the main place to live and produce, but is less relevant in towns and cities where most jobs are outside of agriculture and housing can be rented. In urban areas, housing and residential land play a larger role than agricultural land, but even though city dwellers tend to earn more than their rural compatriots, they are often less likely to own a home (Pendall et al 2016 for the United States; Eurostat 2015 for European Union countries; Sato et al 2011 for China). This reflects partly that land is relatively scarce in urban areas, leading to highpriced real estate, but also better access to financial services, as an alternative means to store wealth. Because of this, some caution must be exercised in comparing ownership of land and housing property across rural and urban areas.

Figure 5 plots gender gaps in property ownership by country, separately for rural and urban areas. Gender gaps in sole ownership are almost always larger in rural than in urban areas. This pattern holds for the most part, though less pronounced, also for gender gaps in sole and joint ownership, though there are some exceptions. This, however, does not mean that women are more likely to own property if they live in urban areas. It rather reflects that urban men are much less likely to own property than their rural counterparts.

To further investigate distributional patterns, we estimate gender gaps by quintile, using the DHS household-level wealth index. As shown in Figure 6, gender gaps in sole property ownership are in most countries larger for the poorest than for the richest quintile, though there are some countries where the opposite pattern holds (Burundi, Jordan, and Mozambique). This income gradient is weaker for joint ownership, where nine out of 40 countries (excluding the Comoros) display larger gaps for the richest than poorest quintile. These differences in gender gaps along the distribution reflect a considerable degree of rural-urban differences. In other words, the poorest quintile is more likely to live in rural areas, where - as shown in Figure 5 - gender gaps in property ownership are larger than in urban areas. 
Figure 5: Gender gaps in property ownership among married couples, urban vs rural areas

(a) Sole ownership of property

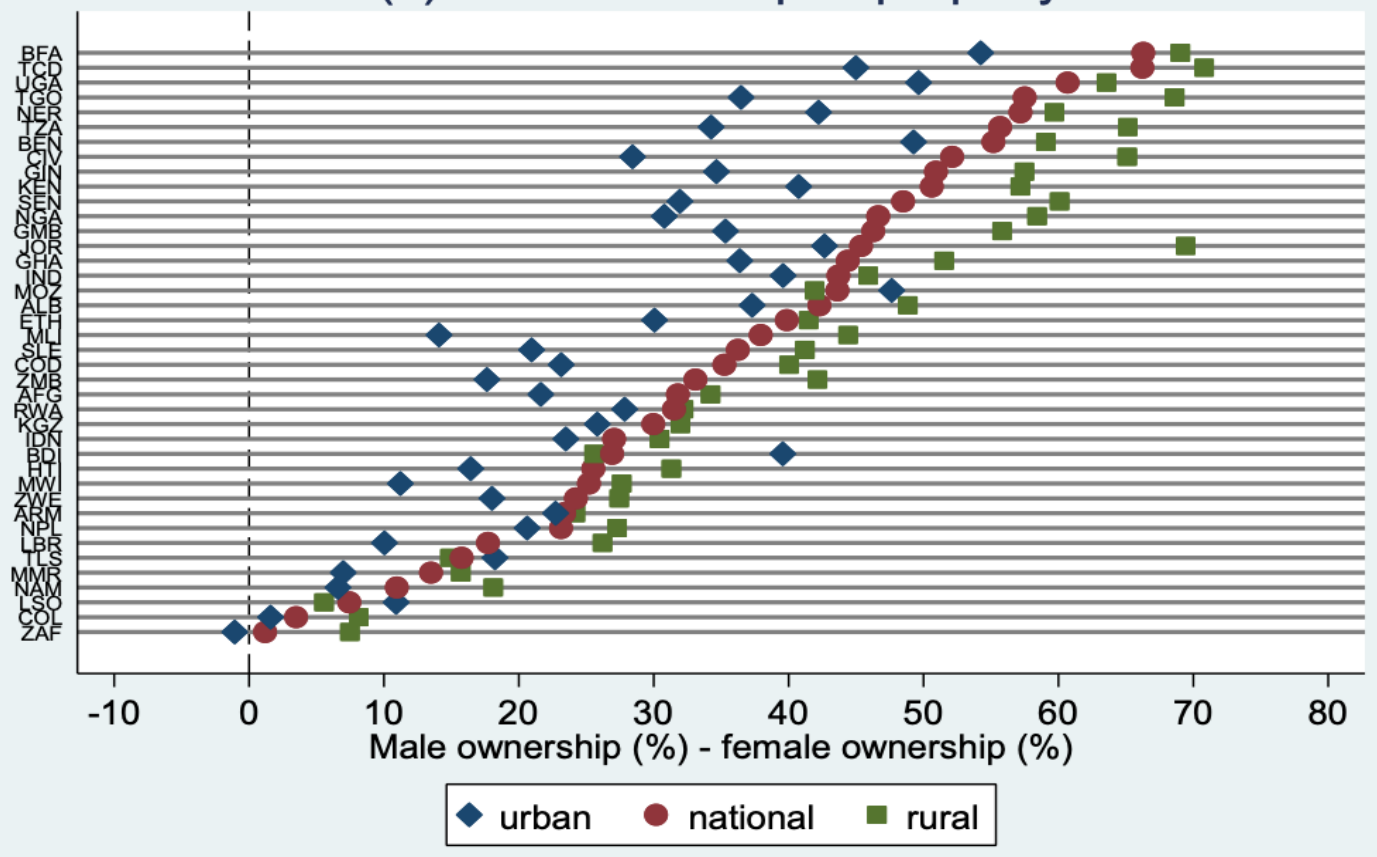

(b) Sole and joint ownership of property

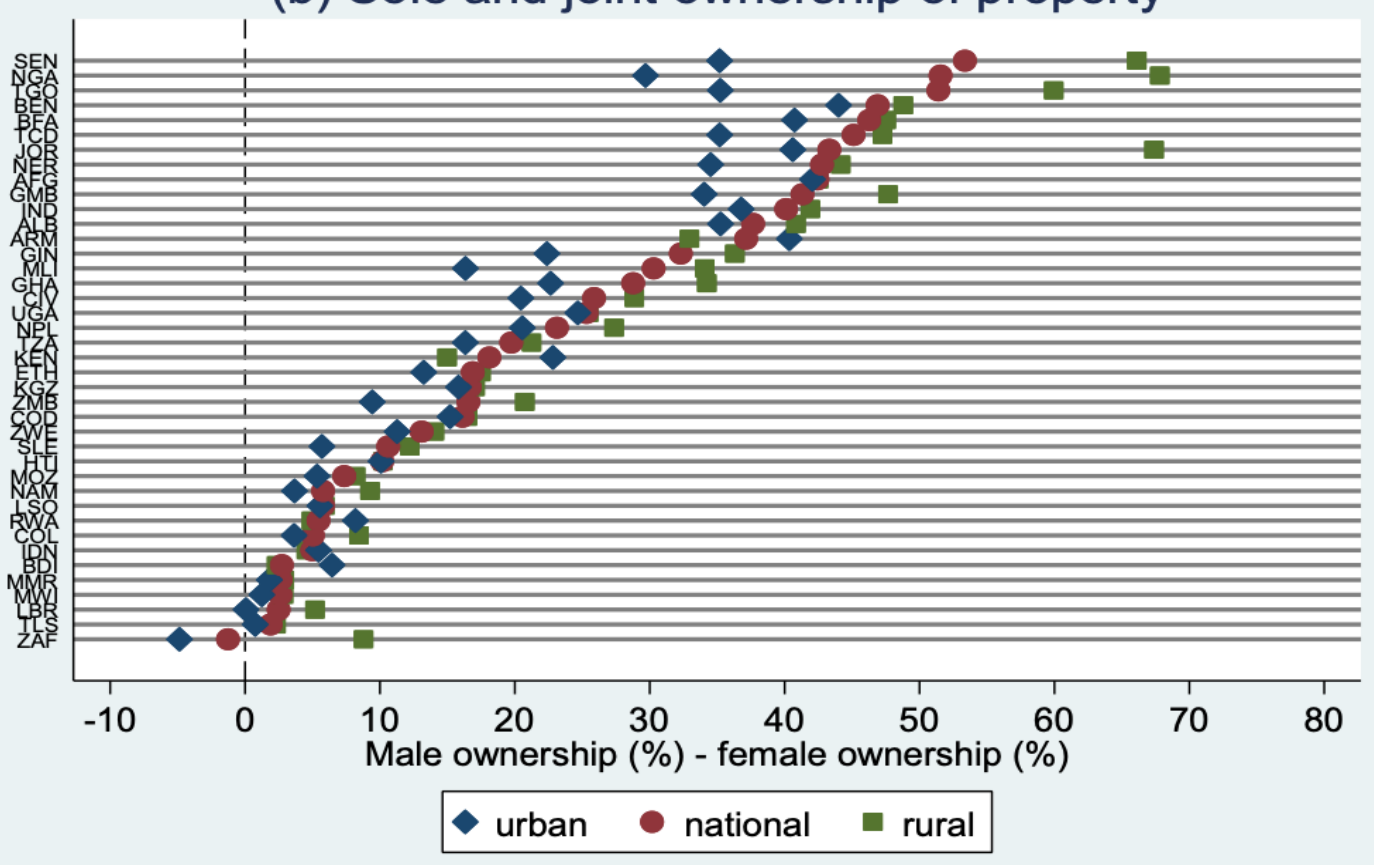

Note: Data for 40 countries from 2010-18 (excluding the Comoros). South Africa and Liberia only have data on housing ownership. Based on DHS couples recode (i.e. married couples). Source: DHS. 
Figure 6: Gender gaps in property ownership among married couples, richest vs. poorest quintile
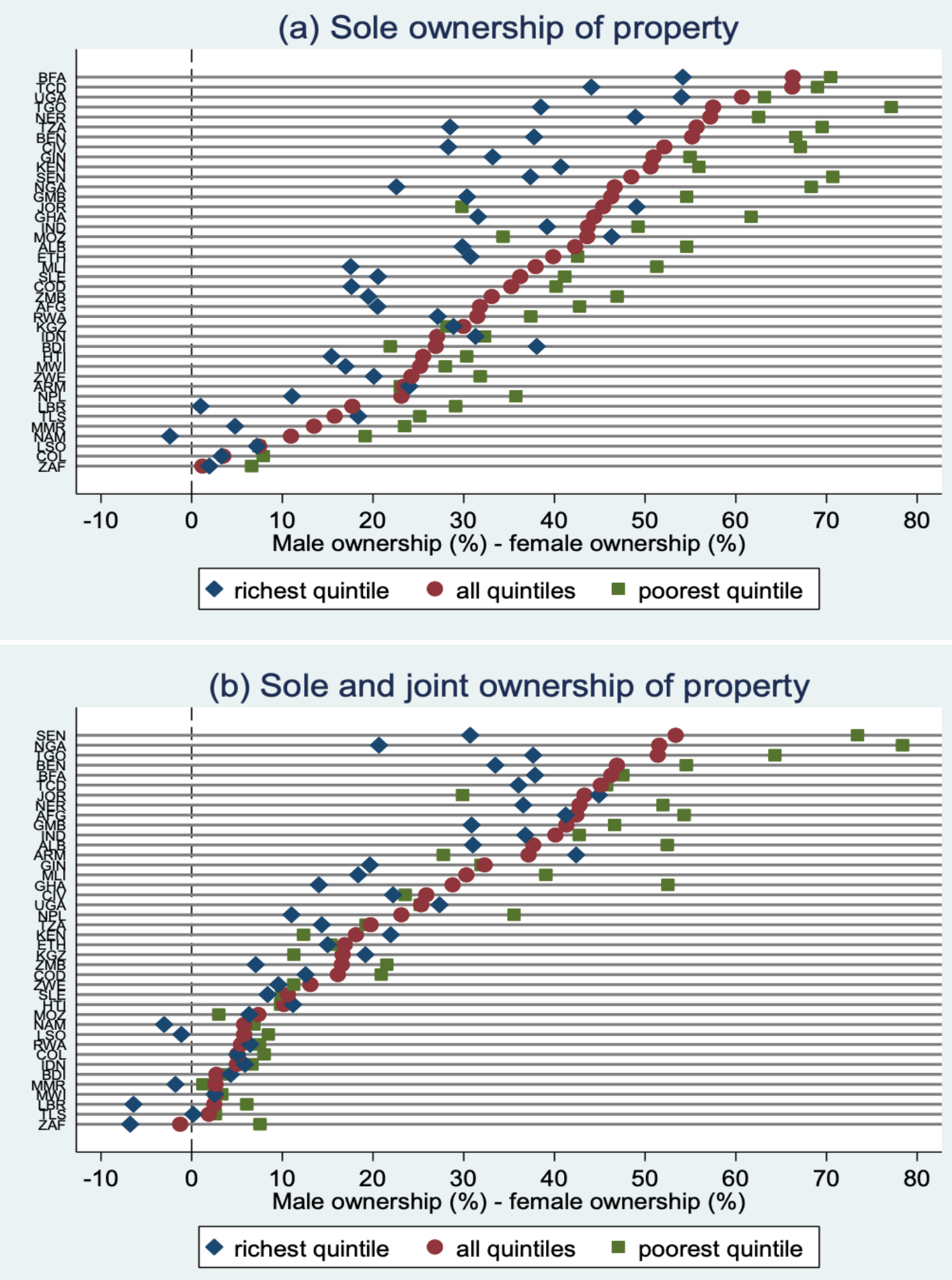

Note: Data for 40 countries from 2010-18 (excluding the Comoros). South Africa and Liberia only have data on housing ownership. Based on DHS couples recode (i.e. married couples). Source: DHS 


\section{Multivariate analysis of women's property ownership}

\subsection{Model specification}

This section investigates what factors are statistically associated with individual property ownership in a multivariate regression framework. This has the advantage that, unlike with the descriptive statistics, we can control for confounding factors. For example, despite recent gains in girls' school enrollments, adult women still have lower levels of education than men in many of the countries in our sample, and this may have an impact on their property ownership. In addition, regression analysis is a useful way to summarize the relationship between various explanatory variables and our outcome of interest, wife's property ownership, even as we are careful not to make causal claims due to the cross-sectional nature of the data.

We estimate the following model:

$$
\mathrm{Y}_{\mathrm{irc}}=\beta \mathrm{W}_{\mathrm{c}}+\gamma \mathrm{K}_{\mathrm{c}}+\delta \mathrm{G}_{\mathrm{c}}+\zeta \mathrm{X}_{\mathrm{irc}}+\eta \mathrm{Z}_{\mathrm{irc}}+\omega+\varepsilon
$$

where $Y_{\text {irc }} i$ s a binary variable that equals unity if the wife (living in region $r$, country $c$ ) owns any property, either alone or jointly with the husband or others; and zero otherwise. We estimate a linear probability model (LPM), rather than a logit or probit model for ease of exposition. Standard errors are clustered at the country level, because our main variables of interest (laws) do not vary within countries.

$\mathrm{W}_{\mathrm{c}}$ is a vector of country-specific legal variables that might have an impact on women's ownership of assets. These include the WBL variables discussed in section 2, which indicate the role of gender discrimination in the country's legal system - i.e. whether the law recognizes nonmonetary contributions to marital property (Figure 1), and if men and women have equal inheritance rights (Figures 2a and 2b). Given the large degree of overlap between the countries that discriminate by gender on natal inheritance and spousal inheritance, the two variables on inheritance are merged into a single variable. We include an additional variable that measures if men and women have equal ownership rights to immovable property. This picks up discrimination by gender not only in the legal ability to own property, but also in the legal treatment of spousal property. Thus, in countries where husbands are granted the administrative right of marital property, this variable would take on a value of 0 . The fourth variable in this set relates to pay equality and captures if the law mandates equal remuneration for work of equal value (Figure 3 ).

The WBL variables under consideration in the empirical analysis broadly reflect the pathways to property ownership by women discussed in section 2 . We expect that laws discriminating against women in property use and ownership and, in the workplace, may have a negative association with their ability to own any land or housing, either solely or jointly with someone else. The variable on the valuation of nonmonetary contributions captures two related pathways to asset accumulation - via equal rights for women in marital and spousal assets (depending on full or partial community of property) and recognizing women's contribution to social reproduction and the care economy. The gendered division of labor and expectations that women are responsible for the home in practically every country constrain women's ability to fully realize their potential in the labor market which negatively impacts their earnings. Finally, discrimination in the workplace is captured by looking at legislations that mandate equal remuneration (including emoluments in cash or in-kind) for equal work. Such laws increase the likelihood that women in 
the labor force will have an opportunity to accumulate savings to acquire property through market transactions.

$\mathrm{K}_{\mathrm{c}}$ is the second vector of country-specific variables representing both historical and current cultural attitudes and social norms surrounding gendered roles and responsibilities, and gender equality more broadly, that may enhance or diminish the effectiveness of current antidiscriminatory legislations (Deere et al 2013; Giuliano 2017). While gender inequality can be all encompassing and affects women from the cradle to the grave, we focus on those cultural attributes that we believe could be correlated with property rights. Following the definitions of Alesina et al (2013), we control for the absence of private property, rules governing post-marital residence, and family structure. The authors revisit Engels (1902) argument regarding the emergence of private property being detrimental for women's autonomy. According to Engels (1902), the control of private property by men also led to control and suppression of women to protect paternity. In certain regions, such as South Asia, patrilocality is often accompanied by residence with the husband's extended family with differential impacts on women's agency and wellbeing (Khalil and Mookerjee 2019); this could also impact their property rights. It is also plausible that in patrilocal societies, girls may be denied a share of natal inheritance, particularly in rural areas, citing their inability to administer the property. Lastly, this set includes religion of the current population to pick up deep-seated social attitudes to gender equality including women's rights to own and use property. Even in countries with constitutional guarantees for gender equality, religious beliefs may drive much of what is commonly accepted and practiced in societies and therefore affect women's property ownership (see, for example, Evans 2015 for qualitative evidence from Senegal).

We also control for GDP per capita and its square, $G_{c}$; this is a proxy for a potentially nonlinear relationship between the economic development of the country and gender gaps in property ownership.

$X_{i r c}$ is vector of characteristics of the couple $i$. These include (separately) the wife's and husband's number of sons and daughters ever born, age and age squared, years of education (as a categorical variable) and employment status as well as the husband-wife education gap and a variable that equals unity if both spouses are working. $Z_{\text {irc }}$ is a vector of household characteristics and includes who in the survey is assigned the head of the household.

We run three different models, all with world region fixed-effects that control for timeinvariant unobservable regional characteristics. The first model includes the WBL variables and per capita GDP (linear and squared); the second one adds the cultural and social norms related variables; the final third model adds characteristics of the couple and household.

As discussed earlier, gender gaps in property ownership are strongly influenced by the urbanrural makeup of the sample, with gender gaps generally being much larger in rural than urban areas. We, therefore, run the regressions separately for urban and rural areas. We also run the models separately for ownership of land and housing. Each of the regressions is run on the couple sample, pooling observations from 41countries for housing ownership, and from 39 countries for land ownership. In total, our analysis amounts to 213,898 couples for housing $(142,585$ in rural areas and 71,313) and 211,310 couples for land ownership (141,024 in rural areas and 70,286 in 
urban areas). ${ }^{10}$ Mean statistics for all variables used in the regressions are shown in Table A4 for the urban and rural subsamples.

Besides the DHS data for the couple sample, the paper draws on the following country-level databases (see Table A1 for data definition). The Women Business and the Law (WBL) program provides data on laws and regulations constraining women's property ownership and economic opportunities (World Bank 2020a). ${ }^{11}$ The World Development Indicators (WDI) provide data on GDP per capita (World Bank 2020b). Data on historical cultural attitudes and social norms are from Alesina et al (2013), while the data on the country's largest religions are drawn from The Association of Religion Data Archives (Harris et al 2019).

\subsection{Results}

Considering the WBL variables we see that the equal remuneration law has the lowest coverage in the sample -- only about 15 to 18 percent in urban and rural areas, respectively (Table A4). Effectively, the share of the population benefitting from such laws is likely even lower, as employment-related legislations do not extend to the informal sector that employs a large proportion of workers in developing countries. Equal ownership rights to immovable property has the widest coverage and applies to more than 90 percent of the sample. Women's incidence of housing ownership is higher than land ownership, and a greater proportion of rural than urban women own some property. Turning to our regression analysis, we find that women living in countries with more gender-egalitarian legal regimes are more likely to own property in both urban and rural areas. We first discuss the results for housing ownership (Table 1). In urban areas, three legal variables, except for the laws providing for equal inheritance rights, are positively and significantly associated with women's chances of owning a house across all models. More genderequitable legislation providing for equal ownership rights for men and women is associated with a 15 to 18 percent increase in the probability to own the house; legislation valuing non-monetary contributions to the marriage is associated with a 11 to 16 percent increase; and legislation mandating equal remuneration for equal work is associated with a 10 percent increase in women's chances of owing the house. In rural areas, equal ownership rights are associated with a 21 percent increase in women's housing ownership, while the valuation of non-monetary contributions is associated with 12 to 20 percent increase in women's housing ownership across the models.

In the case of land, the results are qualitatively similar, but the associations are weaker and significant for only a few legal variables (Table 2). In urban areas, women living in countries where laws provide for the valuation of non-monetary contributions are 8 to 11 percent more likely to own land. Controlling for current religion, historical cultural attitudes and a rich set of couple and household attributes, the other legal variables no longer remain significant. In rural areas, the laws providing for equal ownership rights are significantly associated with women's ownership. For land, the fact that most WBL variables lose significance once the analysis controls for current religion and historical cultural variables (i.e. comparing columns (2) and (3) for both urban and

\footnotetext{
${ }^{10}$ As noted in section 3, two countries (South Africa and Liberia) only collect data on housing and not on land ownership, which explains the smaller sample size for the regressions on land ownership. A few additional observations drop out once we control individual, spouse, couple and household characteristics due to missing values.

${ }^{11}$ Unlike in section 2, where we reported the most recent WBL data (referring to 2020), the multivariate analysis draws on the data referring to 2015 (from the 2020 WBL edition), which are closer in timing to the DHS data in our sample (see Table A2).
} 
rural areas) may be explained by the high correlation between the WBL variables and other country-level historical variables reflecting social norms around inheritance and family structures, which suggests that legislative changes may not be as effective in increasing women's land ownership in environments with adverse social norms.

We briefly discuss our historical and current controls at the country-level. Confirming the descriptive analysis, there is no significant relationship between per capita GDP and property ownership, which suggests that economic prosperity per se is not a key driver of women's property ownership. With respect to the variables reflecting historical cultural attitudes and gender norms only the absence of historical inheritance rights and the prevalence of extended families in the society (especially in rural areas) are significantly associated with women's property ownership. The absence of inheritance rights historically is linked to the absence of private property rights per se, which according to Engels (1902) implies a relatively more gender egalitarian society. A high prevalence of extended families in rural areas has a negative association with both land and housing ownership, reflecting perhaps a larger number of claimants to immoveable property reducing women's chances of even joint ownership. A higher proportion of the population following matrilocality (patrilocality) in the society historically is associated with higher (lower) property ownership among women but the effects are not statistically significant.

Model (3) includes a rich set of individual, spouse, couple and household characteristics. Individual attributes such as age and education of women show the expected associations for property ownership - older women are more likely to own property as are highly educated women (mostly greater than 13 years of education). Wives' property ownership in urban areas is positively impacted when both spouses are working, reflecting greater purchasing ability. Rather surprisingly, women's own employment is either negatively associated (mostly in urban locations) or has no association (mostly in rural locations) on her ownership. Being assigned head of household is beneficial for wives in rural areas when compared to the husband being the head. A wife being considered a head is not a common occurrence in the sample and possibly reflects traditions where lineage is through the woman and/or she is considered a key decision maker. However, a household member other than the husband being assigned the head has negative effects on women's property ownership in rural areas, and across locations if the head is female. This headship structure is indicative of an extended family, where the couple is living with parents or other relatives. Thus, older members are more likely to own the property; even if the husband owns the property it will likely be joint with other household members and not necessarily with his wife.

The regional fixed effects are large and statistically significant in model (1), with all regions experiencing lower ownership rates of immovable property compared to East Asia and the Pacific. However, the regional dummies for South Asia and Sub-Saharan Africa turn insignificant once we control for GDP, religion and historical social norms (in model (2)), indicating that the relative disadvantage of these two regions can be explained by these variables. Conversely, the regional fixed effects for the Middle East and North Africa (except for land in urban areas) and for Latin America and the Caribbean tend to stay negative and significant in models (2) and (3), which suggests that women in those regions are disadvantaged by forces that are not accounted for by our regression models. However, it is important to note that both regions are represented by only a few countries in our sample (Middle East and North Africa: Jordan; Latin America and the Caribbean: Colombia, Haiti) so that the results are not easily generalizable. 
Table 1: Housing ownership

\begin{tabular}{|c|c|c|c|c|c|c|}
\hline & $(1)$ & $\begin{array}{l}\text { Urban } \\
(2)\end{array}$ & (3) & $(1)$ & $\begin{array}{c}\text { Rural } \\
(2)\end{array}$ & (3) \\
\hline \multicolumn{7}{|l|}{ Legal framework of the country: } \\
\hline $\begin{array}{l}\text { Men and women have equal ownership rights } \\
\text { to immovable property }\end{array}$ & $\begin{array}{c}0.153^{* * *} \\
(2.99)\end{array}$ & $\begin{array}{c}0.164^{* * *} \\
(3.07)\end{array}$ & $\begin{array}{c}0.184^{* * *} \\
(3.42)\end{array}$ & $\begin{array}{l}0.212^{* * *} \\
(2.91)\end{array}$ & $\begin{array}{c}0.216^{* * *} \\
(3.02)\end{array}$ & $\begin{array}{c}0.212^{* * *} \\
(3.01)\end{array}$ \\
\hline $\begin{array}{l}\text { Law provides for the valuation of non- } \\
\text { monetary contributions }\end{array}$ & $\begin{array}{l}0.165^{* * *} \\
(3.98)\end{array}$ & $\begin{array}{c}0.120^{* * * *} \\
(2.86)\end{array}$ & $\begin{array}{l}0.114^{* *} \\
(2.64)\end{array}$ & $\begin{array}{l}0.199^{* * *} \\
(2.82)\end{array}$ & $\begin{array}{c}0.141^{* * *} \\
(2.92)\end{array}$ & $\begin{array}{c}0.122^{* *} \\
(2.54)\end{array}$ \\
\hline Law provides for equal inheritance rights & $\begin{array}{l}0.075 \\
(1.47)\end{array}$ & $\begin{array}{l}0.079 \\
(1.13)\end{array}$ & $\begin{array}{l}0.075 \\
(1.11)\end{array}$ & $\begin{array}{l}0.085 \\
(1.50)\end{array}$ & $\begin{array}{l}0.043 \\
(0.56)\end{array}$ & $\begin{array}{l}0.040 \\
(0.53)\end{array}$ \\
\hline $\begin{array}{l}\text { Law mandates equal remuneration for equal } \\
\text { work }\end{array}$ & $\begin{array}{l}0.098^{*} \\
(1.79)\end{array}$ & $\begin{array}{l}0.089 \\
(1.56)\end{array}$ & $\begin{array}{l}0.095^{*} \\
(1.73)\end{array}$ & $\begin{array}{l}0.124 \\
(1.28)\end{array}$ & $\begin{array}{l}0.062 \\
(0.87)\end{array}$ & $\begin{array}{l}0.066 \\
(0.96)\end{array}$ \\
\hline \multicolumn{7}{|l|}{ Other country-level controls: } \\
\hline $\ln$ GDP pc & $\begin{array}{l}-0.465^{*} \\
(-1.84)\end{array}$ & $\begin{array}{l}0.002 \\
(0.01)\end{array}$ & $\begin{array}{l}0.004 \\
(0.01)\end{array}$ & $\begin{array}{l}-0.727 \\
(-1.53)\end{array}$ & $\begin{array}{l}-0.540 \\
(-1.21)\end{array}$ & $\begin{array}{l}-0.426 \\
(-0.99)\end{array}$ \\
\hline ln GDP pc, squared & $\begin{array}{c}0.028 \\
(1.65)\end{array}$ & $\begin{array}{l}-0.002 \\
(-0.07)\end{array}$ & $\begin{array}{l}-0.003 \\
(-0.14)\end{array}$ & $\begin{array}{l}0.040 \\
(1.26)\end{array}$ & $\begin{array}{l}0.030 \\
(1.03)\end{array}$ & $\begin{array}{l}0.023 \\
(0.80)\end{array}$ \\
\hline \multicolumn{7}{|l|}{ Religion (ref: Catholic/Orthodox Christian) } \\
\hline Other Christian & & $\begin{array}{l}-0.059 \\
(-0.87)\end{array}$ & $\begin{array}{l}-0.043 \\
(-0.64)\end{array}$ & & $\begin{array}{l}0.029 \\
(0.40)\end{array}$ & $\begin{array}{l}0.029 \\
(0.42)\end{array}$ \\
\hline Muslim & & $\begin{array}{l}0.011 \\
(0.16)\end{array}$ & $\begin{array}{l}0.013 \\
(0.19)\end{array}$ & & $\begin{array}{l}-0.040 \\
(-0.46)\end{array}$ & $\begin{array}{l}-0.032 \\
(-0.39)\end{array}$ \\
\hline Other & & $\begin{array}{c}-0.189^{*} \\
(-1.91)\end{array}$ & $\begin{array}{l}-0.200^{*} \\
(-2.02)\end{array}$ & & $\begin{array}{l}-0.168 \\
(-1.27)\end{array}$ & $\begin{array}{l}-0.192 \\
(-1.52)\end{array}$ \\
\hline Absence of inheritance & & $\begin{array}{c}0.219^{* * *} \\
(3.78)\end{array}$ & $\begin{array}{c}0.232^{* * *} \\
(4.05)\end{array}$ & & $\begin{array}{c}0.176^{* *} \\
(2.34)\end{array}$ & $\begin{array}{c}0.206^{* *} \\
(2.64)\end{array}$ \\
\hline Matrilocal societies & & $\begin{array}{l}0.070 \\
(0.43)\end{array}$ & $\begin{array}{l}0.060 \\
(0.40)\end{array}$ & & $\begin{array}{l}0.090 \\
(0.47)\end{array}$ & $\begin{array}{l}0.104 \\
(0.56)\end{array}$ \\
\hline Patrilocal societies & & $\begin{array}{c}-0.161^{*} \\
(-1.76)\end{array}$ & $\begin{array}{l}-0.147 \\
(-1.61)\end{array}$ & & $\begin{array}{l}-0.153 \\
(-1.58)\end{array}$ & $\begin{array}{l}-0.122 \\
(-1.30)\end{array}$ \\
\hline Nuclear family & & $\begin{array}{l}0.004 \\
(0.02)\end{array}$ & $\begin{array}{l}0.021 \\
(0.12)\end{array}$ & & $\begin{array}{l}0.277 \\
(1.20)\end{array}$ & $\begin{array}{l}0.312 \\
(1.43)\end{array}$ \\
\hline Extended family & & $\begin{array}{l}-0.211^{*} \\
(-1.72)\end{array}$ & $\begin{array}{l}-0.184 \\
(-1.56)\end{array}$ & & $\begin{array}{l}-0.257^{*} \\
(-1.87)\end{array}$ & $\begin{array}{l}-0.240^{*} \\
(-1.84)\end{array}$ \\
\hline \multicolumn{7}{|l|}{ World region (ref: East Asia \& Pacific) } \\
\hline Europe \& Central Asia & $\begin{array}{c}-0.246^{* * *} \\
(-3.23)\end{array}$ & $\begin{array}{l}-0.010 \\
(-0.07)\end{array}$ & $\begin{array}{l}-0.042 \\
(-0.31)\end{array}$ & $\begin{array}{c}-0.374^{* * *} \\
(-3.68)\end{array}$ & $\begin{array}{l}0.077 \\
(0.43)\end{array}$ & $\begin{array}{c}0.078 \\
(0.44)\end{array}$ \\
\hline Latin America \& Caribbean & $\begin{array}{c}-0.345^{* * *} \\
(-5.50)\end{array}$ & $\begin{array}{c}-0.382^{* * *} \\
(-4.38)\end{array}$ & $\begin{array}{c}-0.350^{* * *} \\
(-4.03)\end{array}$ & $\begin{array}{c}-0.276^{* * *} \\
(-3.42)\end{array}$ & $\begin{array}{c}-0.335^{* * *} \\
(-2.92)\end{array}$ & $\begin{array}{c}-0.329^{* * *} \\
(-2.93)\end{array}$ \\
\hline Middle East \& North Africa & $\begin{array}{c}-0.341^{* * *} \\
(-7.61)\end{array}$ & $\begin{array}{c}-0.229^{* * *} \\
(-2.89)\end{array}$ & $\begin{array}{c}-0.287^{* * *} \\
(-3.58)\end{array}$ & $\begin{array}{c}-0.410^{* * *} \\
(-6.02)\end{array}$ & $\begin{array}{c}-0.258^{* * *} \\
(-3.71)\end{array}$ & $\begin{array}{c}-0.325^{* * *} \\
(-4.56)\end{array}$ \\
\hline South Asia & $\begin{array}{c}-0.161^{* *} \\
(-2.62)\end{array}$ & $\begin{array}{l}0.182 \\
(1.49)\end{array}$ & $\begin{array}{l}0.184^{*} \\
(1.69)\end{array}$ & $\begin{array}{c}-0.260^{* * *} \\
(-5.16)\end{array}$ & $\begin{array}{l}0.230 \\
(1.38)\end{array}$ & $\begin{array}{l}0.254 \\
(1.63)\end{array}$ \\
\hline Sub-Saharan Africa & $\begin{array}{l}-0.324^{* * *} \\
(-5.36)\end{array}$ & $\begin{array}{l}-0.162 \\
(-1.27)\end{array}$ & $\begin{array}{l}-0.169 \\
(-1.44)\end{array}$ & $\begin{array}{l}-0.360^{* * *} \\
(-4.58)\end{array}$ & $\begin{array}{l}-0.037 \\
(-0.25)\end{array}$ & $\begin{array}{l}-0.038 \\
(-0.27)\end{array}$ \\
\hline \multicolumn{7}{|l|}{ Characteristics of the wife: } \\
\hline Wife's total number of sons ever born & & & $\begin{array}{l}0.010^{* *} \\
(2.50)\end{array}$ & & & $\begin{array}{c}0.010^{* * *} \\
(3.03)\end{array}$ \\
\hline Wife's total number of daughters ever born & & & $\begin{array}{c}0.010^{* *} \\
(2.40)\end{array}$ & & & $\begin{array}{c}0.005^{* *} \\
(2.25)\end{array}$ \\
\hline Wife's age in years & & & $\begin{array}{l}-0.002 \\
(-0.41)\end{array}$ & & & $\begin{array}{c}0.010^{* * * *} \\
(3.35)\end{array}$ \\
\hline Wife's age in years, squared & & & $\begin{array}{l}0.000^{*} \\
(1.69)\end{array}$ & & & $\begin{array}{l}-0.000^{* *} \\
(-2.53)\end{array}$ \\
\hline \multicolumn{7}{|l|}{ Wife's education (ref: none) } \\
\hline 1 to 4 years of education & & & $\begin{array}{l}0.012 \\
(1.11)\end{array}$ & & & $\begin{array}{l}0.023^{*} \\
(1.69)\end{array}$ \\
\hline 5 to 8 years of education & & & $\begin{array}{l}0.013 \\
(0.85)\end{array}$ & & & $\begin{array}{l}0.012 \\
(0.55)\end{array}$ \\
\hline 9 to 12 years of education & & & $\begin{array}{l}0.001 \\
(0.04) \\
\end{array}$ & & & $\begin{array}{l}0.024 \\
(1.47) \\
\end{array}$ \\
\hline
\end{tabular}


Table 1: Housing ownership (continued)

\begin{tabular}{|c|c|c|c|c|c|}
\hline 13 or more years of education & & $\begin{array}{l}0.030 \\
(1.27)\end{array}$ & & & $\begin{array}{c}0.052^{* *} \\
(2.03)\end{array}$ \\
\hline \multicolumn{6}{|l|}{ Wife's type of work (ref: not working) } \\
\hline Services & & $\begin{array}{c}-0.055^{* * *} \\
(-2.90)\end{array}$ & & & $\begin{array}{l}-0.032 \\
(-1.46)\end{array}$ \\
\hline Agriculture & & $\begin{array}{l}0.017 \\
(0.48)\end{array}$ & & & $\begin{array}{l}0.033 \\
(1.45)\end{array}$ \\
\hline Industry/manual & & $\begin{array}{c}-0.054^{* * *} \\
(-3.10)\end{array}$ & & & $\begin{array}{l}-0.009 \\
(-0.35)\end{array}$ \\
\hline $\mathrm{DK} /$ missing/other & & $\begin{array}{c}-0.069^{* * *} \\
(-2.74)\end{array}$ & & & $\begin{array}{c}-0.076^{* *} \\
(-2.04)\end{array}$ \\
\hline \multicolumn{6}{|l|}{ Characteristics of the husband: } \\
\hline Husband's total number of sons ever born & & $\begin{array}{l}0.001 \\
(0.54)\end{array}$ & & & $\begin{array}{l}-0.003 \\
(-1.24)\end{array}$ \\
\hline Husband's total number of daughters ever born & & $\begin{array}{l}-0.002 \\
(-0.86)\end{array}$ & & & $\begin{array}{l}-0.003 \\
(-1.60)\end{array}$ \\
\hline Husband's age in years & & $\begin{array}{l}0.010^{*} \\
(1.90)\end{array}$ & & & $\begin{array}{l}0.004 \\
(0.70)\end{array}$ \\
\hline Husband's age in years, squared & & $\begin{array}{l}-0.000 \\
(-1.40)\end{array}$ & & & $\begin{array}{l}-0.000 \\
(-0.54)\end{array}$ \\
\hline \multicolumn{6}{|l|}{ Husband's education (ref: none) } \\
\hline 1 to 4 years of education & & $\begin{array}{l}0.023 \\
(1.19)\end{array}$ & & & $\begin{array}{l}0.020^{*} \\
(1.70)\end{array}$ \\
\hline 5 to 8 years of education & & $\begin{array}{l}0.035^{*} \\
(1.84)\end{array}$ & & & $\begin{array}{l}0.010 \\
(0.84)\end{array}$ \\
\hline 9 to 12 years of education & & $\begin{array}{l}0.035^{*} \\
(1.73)\end{array}$ & & & $\begin{array}{l}-0.001 \\
(-0.08)\end{array}$ \\
\hline 13 or more years of education & & $\begin{array}{c}0.074^{* *} \\
(2.56)\end{array}$ & & & $\begin{array}{l}-0.003 \\
(-0.17)\end{array}$ \\
\hline \multicolumn{6}{|l|}{ Husband's type of work (ref: not working) } \\
\hline Services & & $\begin{array}{l}-0.019 \\
(-0.93)\end{array}$ & & & $\begin{array}{l}-0.036 \\
(-1.56)\end{array}$ \\
\hline Agriculture & & $\begin{array}{l}0.027 \\
(1.22)\end{array}$ & & & $\begin{array}{l}-0.025 \\
(-0.88)\end{array}$ \\
\hline Industry/manual & & $\begin{array}{l}-0.037^{*} \\
(-1.70)\end{array}$ & & & $\begin{array}{l}-0.046^{*} \\
(-1.82)\end{array}$ \\
\hline $\mathrm{DK} / \mathrm{missing} /$ other & & $\begin{array}{l}-0.022 \\
(-0.80)\end{array}$ & & & $\begin{array}{l}-0.038 \\
(-1.11)\end{array}$ \\
\hline \multicolumn{6}{|l|}{ Characteristics of the couple: } \\
\hline Both spouses are working & & $\begin{array}{l}0.032^{*} \\
(1.94)\end{array}$ & & & $\begin{array}{l}0.010 \\
(0.37)\end{array}$ \\
\hline Husband-wife education gap & & $\begin{array}{l}-0.003^{*} \\
(-1.78)\end{array}$ & & & $\begin{array}{l}0.000 \\
(0.08)\end{array}$ \\
\hline \multicolumn{6}{|l|}{ Household headship (ref: husband is head) } \\
\hline Wife head of household & & $\begin{array}{l}0.028 \\
(1.61)\end{array}$ & & & $\begin{array}{c}0.067^{* *} \\
(2.46)\end{array}$ \\
\hline Other male household head & & $\begin{array}{l}-0.035 \\
(-1.22)\end{array}$ & & & $\begin{array}{c}-0.084^{* *} \\
(-2.66)\end{array}$ \\
\hline Other female household head & & $\begin{array}{c}-0.072^{* * *} \\
(-2.85)\end{array}$ & & & $\begin{array}{c}-0.155^{* * *} \\
(-3.63)\end{array}$ \\
\hline Constant & $\begin{array}{c}2.195^{* *} \\
(2.38)\end{array}$ & $\begin{array}{l}0.137 \\
(0.12)\end{array}$ & $\begin{array}{c}3.566^{* *} \\
(2.07)\end{array}$ & $\begin{array}{l}2.737 \\
(1.63)\end{array}$ & $\begin{array}{l}1.994 \\
(1.25)\end{array}$ \\
\hline $\begin{array}{l}\text { Observations } \\
R^{2}\end{array}$ & $\begin{array}{c}71,313 \\
0.05\end{array}$ & $\begin{array}{c}71,122 \\
0.11\end{array}$ & $\begin{array}{c}142,585 \\
0.08\end{array}$ & $\begin{array}{c}142,585 \\
0.11\end{array}$ & $\begin{array}{c}142,324 \\
0.13\end{array}$ \\
\hline
\end{tabular}

Note: Data for 41 countries from 2010-18. $t$ statistics in parentheses. Dependent variable is wife's housing ownership (sole and joint). Coefficients after OLS estimation. Standard errors clustered at the country level. ${ }^{*} p<0.10,{ }^{* *} p<0.05,{ }^{* * *} p<0.01$. Source: DHS. 
Table 2: Land ownership

\begin{tabular}{|c|c|c|c|c|c|c|}
\hline & $(1)$ & $\begin{array}{l}\text { Urban } \\
(2)\end{array}$ & (3) & $(1)$ & $\begin{array}{c}\text { Rural } \\
(2)\end{array}$ & (3) \\
\hline \multicolumn{7}{|l|}{ Legal framework of the country: } \\
\hline \multirow{2}{*}{$\begin{array}{l}\text { Men and women have equal ownership rights } \\
\text { to immovable property }\end{array}$} & 0.094 & 0.042 & 0.062 & $0.160^{* *}$ & $0.115^{*}$ & $0.118^{*}$ \\
\hline & $(1.53)$ & $(0.67)$ & $(1.07)$ & $(2.40)$ & $(1.77)$ & $(1.78)$ \\
\hline \multirow{2}{*}{$\begin{array}{l}\text { Law provides for the valuation of non- } \\
\text { monetary contributions }\end{array}$} & $0.110^{* *}$ & $0.081^{*}$ & $0.077^{*}$ & $0.165^{* * *}$ & $0.097^{* *}$ & 0.073 \\
\hline & $(2.41)$ & $(1.93)$ & $(1.78)$ & $(2.78)$ & $(2.33)$ & $(1.64)$ \\
\hline \multirow{2}{*}{ Law provides for equal inheritance rights } & $0.080^{*}$ & -0.001 & 0.005 & $0.117^{* *}$ & 0.066 & 0.064 \\
\hline & $(1.90)$ & $(-0.02)$ & $(0.09)$ & $(2.15)$ & $(1.03)$ & $(1.02)$ \\
\hline \multirow{2}{*}{$\begin{array}{l}\text { Law mandates equal remuneration for equal } \\
\text { work }\end{array}$} & $0.115^{* *}$ & 0.052 & 0.067 & 0.123 & 0.025 & 0.032 \\
\hline & $(2.18)$ & $(0.94)$ & $(1.24)$ & $(1.34)$ & $(0.35)$ & $(0.47)$ \\
\hline \multicolumn{7}{|l|}{ Other country-level controls: } \\
\hline \multirow[t]{2}{*}{$\ln$ GDP pc } & 0.012 & 0.375 & 0.366 & -0.515 & -0.240 & -0.112 \\
\hline & $(0.03)$ & $(0.80)$ & $(0.86)$ & $(-1.01)$ & $(-0.53)$ & $(-0.26)$ \\
\hline \multirow[t]{2}{*}{ ln GDP pc, squared } & -0.004 & -0.028 & -0.028 & 0.025 & 0.008 & -0.000 \\
\hline & $(-0.18)$ & $(-0.92)$ & $(-1.03)$ & $(0.72)$ & $(0.28)$ & $(-0.01)$ \\
\hline \multicolumn{7}{|l|}{ Religion (ref: Catholic/Orthodox Christian) } \\
\hline \multirow[t]{2}{*}{ Other Christian } & & -0.042 & -0.020 & & 0.068 & 0.072 \\
\hline & & $(-0.60)$ & $(-0.29)$ & & $(0.93)$ & $(1.06)$ \\
\hline \multirow[t]{2}{*}{ Muslim } & & -0.030 & -0.010 & & -0.033 & -0.019 \\
\hline & & $(-0.49)$ & $(-0.18)$ & & $(-0.46)$ & $(-0.27)$ \\
\hline \multirow[t]{2}{*}{ Other } & & 0.011 & 0.016 & & -0.120 & -0.148 \\
\hline & & $(0.11)$ & $(0.17)$ & & $(-0.99)$ & $(-1.26)$ \\
\hline \multirow[t]{2}{*}{ Absence of inheritance } & & $0.125^{* * *}$ & $0.136^{* * *}$ & & 0.090 & $0.125^{* *}$ \\
\hline & & $(3.07)$ & $(3.60)$ & & $(1.41)$ & $(2.05)$ \\
\hline \multirow[t]{2}{*}{ Matrilocal societies } & & 0.205 & 0.171 & & 0.212 & 0.236 \\
\hline & & $(1.14)$ & $(1.04)$ & & $(1.17)$ & $(1.35)$ \\
\hline \multirow[t]{2}{*}{ Patrilocal societies } & & -0.093 & -0.096 & & -0.054 & -0.023 \\
\hline & & $(-0.94)$ & $(-0.98)$ & & $(-0.53)$ & $(-0.23)$ \\
\hline \multirow[t]{2}{*}{ Nuclear family } & & -0.090 & -0.098 & & 0.144 & 0.196 \\
\hline & & $(-0.35)$ & $(-0.41)$ & & $(0.68)$ & $(0.96)$ \\
\hline Extended family & & -0.129 & -0.109 & & $-0.249^{* *}$ & $-0.249^{* *}$ \\
\hline & & $(-1.01)$ & $(-0.88)$ & & $(-2.17)$ & $(-2.32)$ \\
\hline World region (ref: East Asia \& Pacific) & & & & & & \\
\hline Europe \& Central Asia & $-0.321^{* * *}$ & -0.142 & -0.170 & $-0.361^{* * *}$ & -0.019 & -0.003 \\
\hline & $(-6.11)$ & $(-0.90)$ & $(-1.15)$ & $(-5.72)$ & $(-0.12)$ & $(-0.02)$ \\
\hline Latin America \& Caribbean & $-0.229^{* * * *}$ & $-0.198^{* *}$ & $-0.167^{*}$ & $-0.291^{* * *}$ & $-0.292^{* * * *}$ & $-0.281^{* * *}$ \\
\hline & $(-3.70)$ & $(-2.30)$ & $(-1.95)$ & $(-3.52)$ & $(-2.91)$ & $(-2.83)$ \\
\hline Middle East \& North Africa & $-0.170^{* * *}$ & -0.100 & -0.130 & $-0.293^{* * *}$ & $-0.232^{* * *}$ & $-0.279^{* * *}$ \\
\hline & $(-3.28)$ & $(-1.30)$ & $(-1.68)$ & $(-5.42)$ & $(-2.96)$ & $(-3.45)$ \\
\hline South Asia & $-0.120^{*}$ & -0.017 & -0.026 & $-0.258^{* * *}$ & 0.056 & 0.094 \\
\hline & $(-1.96)$ & $(-0.09)$ & $(-0.15)$ & $(-5.09)$ & $(0.33)$ & $(0.59)$ \\
\hline Sub-Saharan Africa & $-0.192^{* * * *}$ & -0.078 & -0.108 & $-0.308^{* * *}$ & -0.113 & -0.112 \\
\hline & $(-3.28)$ & $(-0.46)$ & $(-0.69)$ & $(-4.58)$ & $(-0.73)$ & $(-0.77)$ \\
\hline Characteristics of the wife: & & & & & & \\
\hline Wife's total number of sons ever born & & & $0.007^{*}$ & & & $0.009^{* * *}$ \\
\hline & & & $(1.91)$ & & & $(3.34)$ \\
\hline Wife's total number of daughters ever born & & & $0.008^{* *}$ & & & $0.005^{*}$ \\
\hline & & & $(2.40)$ & & & $(1.99)$ \\
\hline Wife's age in years & & & $0.004^{*}$ & & & $0.006^{* *}$ \\
\hline & & & $(1.76)$ & & & $(2.11)$ \\
\hline Wife's age in years, squared & & & -0.000 & & & -0.000 \\
\hline & & & $(-0.68)$ & & & $(-1.27)$ \\
\hline Wife's education (ref: none) & & & & & & \\
\hline 1 to 4 years of education & & & -0.001 & & & 0.007 \\
\hline & & & $(-0.05)$ & & & $(0.63)$ \\
\hline 5 to 8 years of education & & & 0.017 & & & 0.013 \\
\hline & & & $(1.29)$ & & & $(0.80)$ \\
\hline 9 to 12 years of education & & & 0.024 & & & $0.028^{*}$ \\
\hline & & & $(1.35)$ & & & $(2.02)$ \\
\hline
\end{tabular}


Table 2: Land ownership (continued)

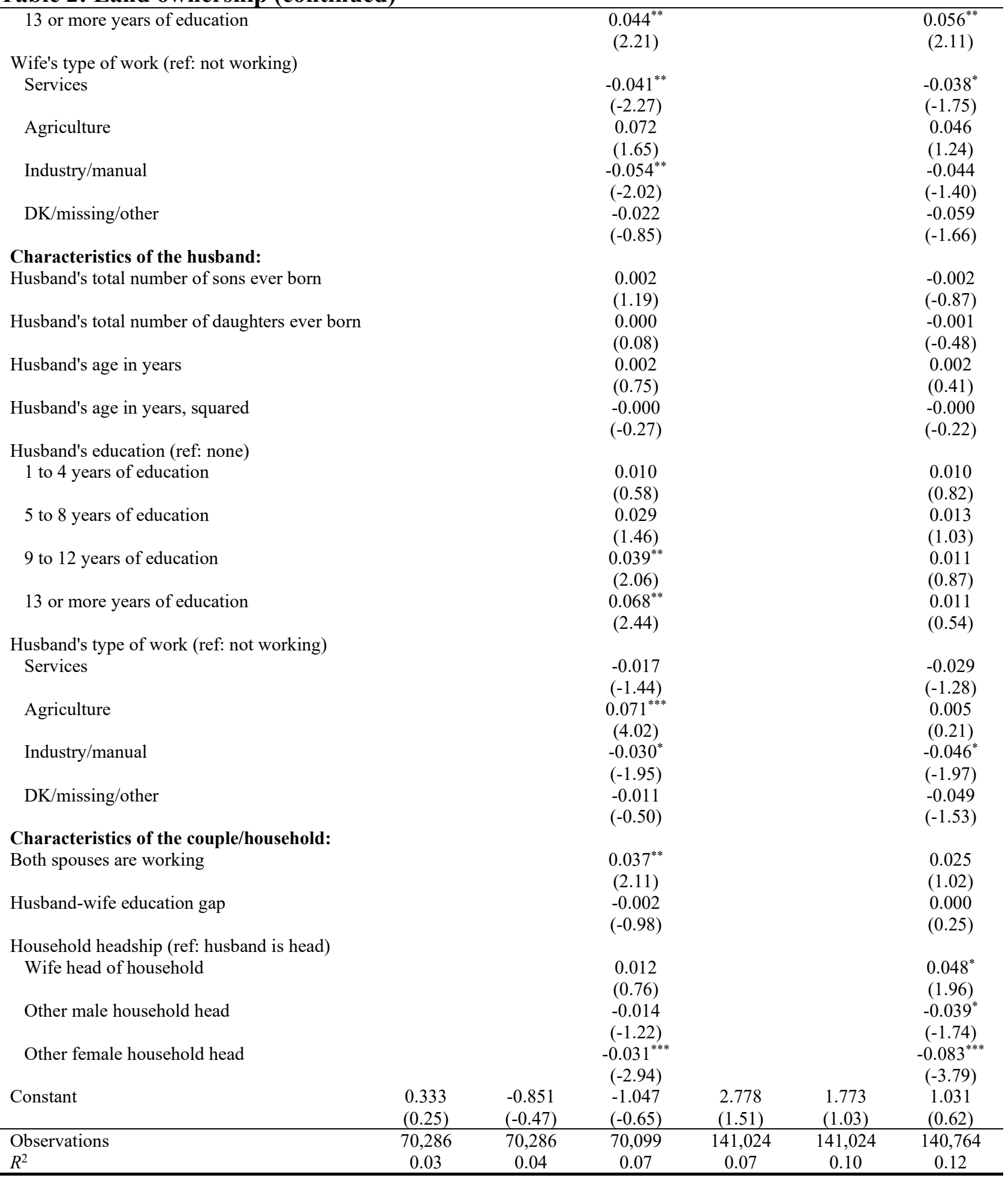

Note: Data for 39 countries from 2010-18. $t$ statistics in parentheses. Dependent variable is wife's land ownership (sole and joint). Coefficients after OLS estimation. Standard errors clustered at the country level. ${ }^{*} p<0.10,{ }^{* *} p<0.05,{ }^{* * *} p<0.01$. Source: DHS. 
To test the robustness of our results to different specifications, we analyze the determinants of women's ownership of property using a multinomial regression model. The dependent variable has three categories - no one in the household owns the asset, the husband owns the asset alone or jointly with someone else (but not the wife) and the wife owns the asset alone or jointly with someone else (including her husband). The results are qualitatively similar (Table A5) to the results from the LPM model. Women in countries with more egalitarian laws are more likely to own property than women in countries with less egalitarian laws. The impact is stronger for housing than for land. Even the magnitude of estimates is similar as in the LPM models. Egalitarian laws reduce the probability of no one in the household owning land, but this is not consistently significant across models. The impact of laws on husbands' chances of owning property is either insignificant or negative across models, except for equal remuneration laws in rural areas which increase husbands' chances of owning land significantly.

\section{Conclusions}

This paper investigates the extent of gender gaps in the incidence of property ownership (land and housing) and the factors associated with these gaps in developing countries, focusing on the role of legal systems. Using DHS data from 41 developing countries, we find that there is substantial variation in gender gaps across countries. However, in almost all countries men are more likely to own property than women and gender gaps are most prominent among the rural population and the poorest quintile. There is significant evidence from the existing literature that women's disadvantage in property ownership limits their bargaining power within the marriage and their fallback options on the dissolution of marriage or on the death of the husband.

The disadvantage in property ownership experienced by women reflects a variety of factors, most importantly discriminatory property laws. Countries with more equal legal regimes for women are associated with higher property ownership by women. The relationship between the legislation and women's property ownership holds across rural and urban areas and is stronger for housing than for land ownership. Our results further suggest that equal rights to own property and laws providing for the valuation of non-monetary contributions may matter more for married women's property ownership than inheritance rights and laws mandating equal remuneration for equal work. Even though we have controlled for a range of country-level and individual characteristics in our model, some of the association between laws and women's property ownership might capture omitted variables that are also positively associated with egalitarian laws. Egalitarian laws come up by a process of advocacy by groups or social movements demanding these rights and a certain level of acceptance of rights by the society. Thus, the association between egalitarian laws and women's property ownership observed here is a culmination of the process that results in making laws and changing gender norms in society.

The results in this paper are consistent with recent studies showing that legislative reforms can affect women's property ownership. For example, Deininger et al $(2013,2018)$ argue that inheritance reforms in India, which removed discriminatory provisions against girls, had a positive effect on the likelihood of daughters to inherit land and increased the amount of assets (including land) daughters brought into marriage. ${ }^{12}$ Likewise, impact evaluation studies show that land

\footnotetext{
${ }^{12}$ Roy (2015), however, argues that the reforms of the Hindu Succession Act failed to increase the likelihood of women inheriting property as parents appear to be 'gifting' land to their sons in order to circumvent the law.
} 
registration programs (e.g. land demarcation, titling or certification) that promote joint registration of both spouses can improve land ownership and tenure security among women and reduce gender gaps when coupled with a conducive legislative framework (O'Sullivan 2017; Ali et al 2014; Goldstein et al 2018). This paper also complements the growing body of literature that documents a relationship between gender-equitable laws and women's economic opportunities (e.g. Htun et al 2019; Islam et al 2019; Hyland et al forthcoming).

However, the effectiveness of legislative changes is conditioned by sticky social norms in an environment where women are in general seen as less valuable than men (Deere et al 2013). These may even lead to perverse effects as found by Bhalotra et al (2020b) in India, where the inheritance reforms increased female feticide. Moreover, in areas with traditional social norms and large gender gaps in property ownership, men may underestimate women's preference for owning immovable property, thus leading to information asymmetries (Najjar et al 2020). This might open another channel for improving women's property ownership - correcting or updating husbands' beliefs about the preferences of their wives (e.g. using an intervention that is similar in spirit to Bursztyn et al forthcoming). Our results also provide an argument for deepening legislative reforms by enacting new anti-discriminatory laws (e.g. moving away from a separation of property marital regime, eliminating employment-related discriminations), enhancing the ambit of current laws (e.g. extending employment laws to the formal and informal sector), and working towards more effective implementation of existing laws.

There are some limitations to the analysis presented here due to the DHS data, which only provide information on the incidence of property ownership. Information on how property assets are acquired by both men and women would help in understanding where the gaps originate from and why they persist. Data on various dimensions of ownership - reported, legal and rights-based - could unpack what asset ownership means for the individual. Individuals may not be legal owners of property, but still enjoy decision-making power over how the property is used or to whom it is bequeathed. Data on the value of assets owned are useful to assess differences between men and women in property wealth. In addition, panel data of individual property ownership, or at least repeated cross-sections, would allow researchers to measure changes in women's and men's property ownership over time and support the identification of causal relationships. Emerging bestpractice standards (e.g. Doss et al 2013, 2020) for the collection of individual-level data on ownership, use and control of assets are an important milestone towards advancing this data collection and analytic agenda. 


\section{References}

ADB (Asian Development Bank). 2017. Key Indicators for Asia and the Pacific. 2017. 48 Edition. Manila: Asian Development Bank.

Agarwal, Bina. 2003. "Gender and Land Rights Revisited: Exploring New Prospects via the State, Family and Market.” Journal of Agrarian Change 3(1/2): 184-224.

Akresh, Richard, Damien de Walque and Harounan Kazianga. 2016. "Alternative Cash Transfer Delivery Mechanisms: Impacts on Routine Preventative Health Clinic Visits in Burkina Faso.” In: African Successes, Volume II: Human Capital, by: Sebastian Edwards, Simon Johnson and David N. Weil (eds.). National Bureau of Economic Research Conference Report, Chicago, IL: University of Chicago Press.

Alesina, Alberto, Paola Giuliano and Nathan Nunn. 2013. "On the Origins of Gender Roles: Women and the Plough." Quarterly Journal of Economics 128(2): 469-530.

Ali, Daniel A., Klaus Deininger and Markus Goldstein. 2014. "Environmental and Gender Impacts of Land Tenure Regularization in Africa: Pilot Evidence from Rwanda." Journal of Development Economics 110: 262-275.

Allendorf, Keera. 2007. "Do Women's Land Rights Promote Empowerment and Child Health in Nepal?" World Development 35(11): 1975-88.

Anderson, Siwan. 2007. "The Economics of Dowry and Brideprice." Journal of Economic Perspectives 21(4): 151-74.

Ansell, Nicola. 2001. "Because It's Our Culture! (Re)Negotiating the Meaning of "Lobola' in Southern African Secondary Schools.” Journal of Southern African Studies 27(4): 697-716.

Arunachalam, Raj and Trevon Logan. 2008. "Is There Dowry Inflation in South Asia?" NBER Working Paper 13905. Cambridge, MA: National Bureau of Economic Research.

Beegle, Kathleen, Elizabeth Frankenberg and Duncan Thomas. 2001. "Bargaining Power Within Couples and Use of Prenatal and Delivery Care in Indonesia." Studies in Family Planning 32(2): 130-46.

Behrman, Julia Andrea. 2017. "Women's Land Ownership and Participation in Decision-making about Reproductive Health in Malawi." Population and Environment 38(4): 327-44.

Bertrand, Marianne. 2020. "Gender in the Twenty-First Century." AEA Papers ad Proceedings 110: 1-24.

Bhalotra, Sonia, Abhishek Chakravarty and Selim Gulesci. 2020a. "The Price of Gold: Dowry and Death in India." Journal of Development Economics 143: 1-17.

Bhalotra, Sonia, Rachel Brulé and Sanchari Roy. 2020b. "Women's Inheritance Rights Reform and the Preference for Sons in India." Journal of Development Economics 146: 1-15.

Bursztyn, Leonardo, Alessandra L. González and David Yanagizawa-Drott. Forthcoming. "Misperceived Social Norms: Women Working Outside the Home in Saudi Arabia." American Economic Review. Retrieved from: https://www.aeaweb.org/articles?id=10.1257/aer.20180975

Corno, Lucia and Alessandra Voena. 2016. "Selling Daughters: Age of Marriage, Income Shocks and the Bride Price Tradition.” IFS Working Paper W16/08. London, UK: Institute for Fiscal Studies (IFS).

Deere, Carmen D. and Cheryl R. Doss. 2006. "The Gender Asset Gap: What Do We Know and Why Does It Matter?” Feminist Economics 12(1-2): 1-50. 
Deere, Carmen D. and Magdalena Leon. 2003. "The Gender Asset Gap: Land in Latin America." World Development 31(6): 925-47.

Deere, Carmen D., Abena D. Oduro, Hema Swaminathan, Cheryl Doss. 2013. "Property Rights and the Gender Distribution of Wealth in Ecuador, Ghana and India." Journal of Economic Inequality 11: 249-65.

Deininger, Klaus, Aparajita Goyal and Hari Nagarajan. 2013. "Women's Inheritance Rights and Intergenerational Transmission of Resources in India." Journal of Human Resources 48(1): 114-41.

Deininger, Klaus, Fang Xia, Songqinq Jin, and Hari Nagarajan. 2018. "Inheritance Law Reform, Empowerment, and Human Capital Accumulation: Second-Generation Effects from India." The Journal of Development Studies 1-23.

Dekker, Marleen and Hans Hoogeveen. 2002. "Bride Wealth and Household Security in Rural Zimbabwe." Journal of African Economies 11(1): 114-45.

Demirgüç-Kunt, Asli, Leora Klapper, Dorothe Singer, Saniya Ansar and Jake Hess. 2018. "The Global Findex Database 2017: Measuring Financial Inclusion and the Fintech Revolution." Washington, DC: World Bank.

Dillon, Brian and Alessandra Voena. 2017. "Inheritance Customs and Agricultural Investment." Retrieved from https://papers.ssrn.com/sol3/papers.cfm?abstract id=2913102

Doss, Cheryl, Caitlin Kieran and Talip Kilic. 2020. "Measuring Ownership, Control and Use of Assets." Feminist Economics 26(3): 144-68.

Doss, Cheryl, Caren Grown, Carmen Diana Deere. 2008. "Gender and Asset Ownership: A Guide to Collecting Individual-level Data.” Policy Research Working Paper 4704, Washington, DC: World Bank.

Doss, Cheryl, Chiara Kovarik, Amber Peterman, Agnes Quisumbing and Mara van den Bold. 2015. "Gender Inequalities in Ownership and Control of Land in Africa: Myth and Reality." Agricultural Economics 46: 403-34.

Doss, Cheryl, Sung Mi Kim, Jemimah Njuki, Emily Hillenbrand and Maureen Miruka. 2014. "Women's Individual and Joint Property Ownership." IFPRI Discussion Paper 01347. Washington, DC: International Food Policy Research Institute.

Doss, Cheryl, William Baah-Boateng, Louis Boakye-Yiadom, Zachary Catanzarite, Carmen Diana Deere, Hema Swaminathan, Rahul Lahoti, Suchitra J.Y. 2013. "Measuring Personal Wealth in Developing Countries: Interviewing Men and Women about Asset Values." The Gender Asset Gap Project, Working Paper 15. Bangalore, India: Indian Institute of Management.

Doss, Cheryl. 2005. "The Effects of Intrahousehold Property Ownership on Expenditure Patterns in Ghana." Journal of African Economies 15(1): 149-80.

Duflo, Esther and Christopher Udry. 2004. "Intrahousehold Resource Allocation in Cote d'Ivoire: Social Norms, Separate Accounts and Consumption Choices.” NBER Working Paper 10498. Cambridge, MA: National Bureau of Economic Research.

Engels, Frederick. 1902. The Origin of the Family, Private Property, and the State. Chicago, IL: Charles H. Kerr \& Company Cooperative.

Eurostat. 2015. People in the EU: Who Are We and How Do We Live? Luxembourg: Publications Office of the European Union.

Evans, Ruth. 2015. "Working with Legal Pluralism: Widowhood, Property Inheritance, and Poverty Alleviation in Urban Senegal.” Gender \& Development 23(1): 77-94. 
Fafchamps, Marcel and Agnes Quisumbing. 2005. “Assets at Marriage in Rural Ethiopia.” Journal of Development Economics 77: 1-25.

Gaddis, Isis and Stephan Klasen. 2014. "Economic Development, Structural Change, and Women's Labor Force Participation: A Reexamination of the Feminization U Hypothesis." Journal of Population Economics 27(3): 639-81.

Gaddis, Isis, Rahul Lahoti and Wenjie Li. 2018. "Gender Gaps in Property Ownership in SubSaharan Africa." Policy Research Working Paper 8573, Washington, DC: World Bank.

Giuliano, Paola. 2017. “Gender: An Historical Perspective." NBER Working Paper 23635. Cambridge, MA: National Bureau of Economic Research.

Goldschmidt, Walter. 1974. "The Economics of Brideprice among the Sebei and in East Africa." Ethnology 13(4): 311-31.

Goldstein, Markus and Christopher Udry. 2008. "The Profits of Power: Land Rights and Agricultural Investment in Ghana." Journal of Political Economy 116(6): 981-1022.

Goldstein, Markus, Kenneth Houngbedji, Florence Kondylis, Michael O'Sullivan and Harris Selod. 2018. "Formalizing Without Certification? Experimental Evidence on Property Rights and Investment." Journal of Development Economics 132(C): 57-74.

Grown, Caren, Greeta Rao Gupta and Aslihan Kes. 2005. Taking Action: Achieving Gender Equality and Empowering Women. UN Millennium Project. Task Force on Education and Gender Equality. London and Sterling, VA: Earthscan.

Hallward-Driemeier, Mary and Tazeen Hasan. 2013. Empowering Women. Legal Rights and Economic Opportunities in Africa. Washington, DC: World Bank.

Harrell, Stevan and Sara. A. Dickey. 1985. "Dowry Systems in Complex Societies." Ethnology 24(2): 105-20.

Harris, Jaime, Robert R. Martin, Sarah Montminy and Roger Finke. 2019. Cross-National SocioEconomic and Religion Data. 2011. Version Feb. 10, 2019. Retrieved from: http://www.thearda.com/Archive/Files/Descriptions/ECON11.asp (accessed August 17, 2020).

Htun, Mala, Francesca R. Jensenius and Jami Nelson-Nuñez. 2019. "Gender-Discriminatory Laws and Women's Economic Agency.” Social Politics 26(2): 193-222.

Hudson, Valerie M. and Hilary Matfess. 2017. "In Plain Sight. The Neglected Linkage Between Brideprice and Violent Conflict." International Security 42(1): 7-40.

Hyland, Marie, Simeon Djankov and Pinelopi Goldberg. Forthcoming. "Gendered Laws and Women in the Workforce." American Economic Review: Insights.

ICF International. 2012. Demographic and Health Survey Interviewer's Manual. MEASURE DHS Basic Documentation No. 2. Calverton, MD: ICF International.

Islam, Asif, Silvia Muzi and Mohammad Amin. 2019. "Unequal Laws and the Disempowerment of Women in the Labour Market: Evidence from Firm-Level Data." Journal of Development Studies 55(5): 822-44.

Jackson, Cecile. 2003. "Gender Analysis of Land: Beyond Land Rights for Women?" Journal of Agrarian Change 3(4): 453-80.

Jacobs, Krista and Aslihan Kes. 2015. "The Ambiguity of Joint Asset Ownership: Cautionary Tales from Uganda and South Africa." Feminist Economics 21(3): 23-55.

Jacobs, Krista, Sophie Namy, Aslihan Kes, Urmilla Bob and Vadivelu Moodley. 2011. Gender Differences in Asset Rights in KwaZulu-Natal, South Africa." Gender Land and Asset Survey. International Center for Research on Women (ICRW). 
Jayachandran, Seema. 2020. "Social Norms as a Barrier to Women's Employment in Developing Countries." NBER Working Paper 27449. Cambridge, MA: National Bureau of Economic Research.

Kabeer, Naila. 1999. "Resources, Agency, Achievements: Reflections on the Measurement of Women's Empowerment.", Development and Change 30: 435-64.

Kes, Aslihan, Krista Jacobs and Sophie Namy. 2011. Gender Differences in Asset Rights in Uganda. Gender Land and Asset Survey. International Center for Research on Women (ICRW).

Khalil, Umair and Sulagna Mookerjee. 2019. "Patrilocal Residence and Women's Social Status: Evidence from South Asia." Economic Development and Cultural Change 67(2): 401-38.

Kilic, Talip, and Heather Moylan. 2016. "Methodological Experiment on Measuring Asset Ownership from a Gender Perspective: Technical Report.” Washington, DC: World Bank. Retrieved from https://goo.gl/fhJtsj.

Klasen, Stephan. 2019. "What Explains Uneven Female Labor Force Participation Levels and Trends in Developing Countries?" World Bank Research Observer 34(2): 161-97.

Klasen, Stephan. 2020. “From 'MeToo' to Boko Haram: A Survey of Levels and Trends of Gender Inequality in the World." World Development 128: 1-10.

Lambert, Sylvie, Martin Ravallion and Dominique van de Walle. 2014. "Intergenerational Mobility and Interpersonal Inequality in an African Economy." Journal of Development Economics 110: 327-44.

Luke, Nancy and Kaivan Munshi. 2011. "Women as Agents of Change: Female Income and Mobility in India." Journal of Development Economics 94: 1-17.

Lundberg, Shelly J. and Robert A. Pollak. 1996. "Bargaining and Distribution in Marriage." Journal of Economic Perspectives 10(4): 139-58.

Lundberg, Shelly J., Robert A. Pollak and Terence J. Wales. 1997. "Do Husbands and Wives Pool Their Resources? Evidence from the United Kingdom Child Benefits." Journal of Human Resources, 32(3): 463-80.

Maitra, Sudeshna. 2007. "Dowry and Bride Price." Prepared for the International Encyclopedia of the Social Sciences, $2^{\text {nd }}$ Edition.

Retrieved

from: http://citeseerx.ist.psu.edu/viewdoc/download?doi=10.1.1.533.3628\&rep=rep1\&type=pdf

Manser, Marilyn and Murray Brown. 1980. "Marriage and Household Decision-Making: A Bargaining Analysis." International Economic Review 21(1): 31-44.

McElroy, Marjorie and Mary Jean Horney. 1981. "Nash-Bargained Household Decisions: Toward a Generalization of the Theory of Demand." International Economic Review 22(2): 333-49.

Menon, Nidhiya, Yana van der Meulen Rodgers and Huong Nguyen. 2014. "Women's Land Rights and Children's Human Capital in Vietnam." World Development 54: 18-31.

Mishra, Khushbu and Abdoul G. Sam. 2016. "Does Women's Land Ownership Promote Their Empowerment? Empirical Evidence from Nepal." World Development 78: 360-71.

Najjar, Dina, Bipasha Baruah and Aman El Garhi. 2020. "Gender and Asset Ownership in the Old and New Lands of Egypt." Feminist Economics 26(3): 119-43.

O'Sullivan, Michael, Arathi Rao, Raka Banerjee, Kajal Gulati and Margaux Vinez. 2014. Levelling the Field: Improving Opportunities for Women Farmers in Africa. Washington, DC: World Bank and ONE Campaign. 
O'Sullivan, Michael. 2017. "Gender and Property Rights in Sub-Saharan Africa. A Review of Constraints and Effective Interventions." Policy Research Working Paper 8250, Washington, DC: World Bank.

Oduro, Abena D., Carmen D. Deere and Zachary B. Catanzarite. 2015. "Women's Wealth and Intimate Partner Violence: Insights from Ecuador and Ghana." Feminist Economics 21(2): 129.

Oduro, Abena D., Louis Boakye-Yiadom and William Baah-Boateng. 2012. "Asset Ownership and Egalitarian Decision-Making among Couples: Some Evidence from Ghana." The Gender Asset Gap Project, Working Paper 14. Bangalore, India: Indian Institute of Management.

Panda, Pradeep and Bina Agarwal. 2005. "Marital Violence, Human Development and Women's Property Status in India." World Development 33(5): 823-50.

Pande, Rohini and Christopher Udry. 2005. "Institutions and Development: A View from Below." In Proceedings of the 9th World Congress of the Econometric Society, by R. Blundell, W. Newey and T. Persson (eds.), Cambridge University Press, pp. 349-403.

Pendall, Rolf, Laurie Goodman, Jun Zhu and Amanda Gold. 2016. The Future of Rural Housing. Research Report. Washington, DC: Urban Institute.

Qian, Nancy. 2008. "Missing Women and the Price of Tea in China: The Effect of Sex-Specific Earnings on Sex Imbalance." Quarterly Journal of Economics 123(3): 1251-85.

Quisumbing, Agnes. R. and Bénédicte de la Brière. 2000. "Women's Assets and Intrahousehold Allocation in Rural Bangladesh: Testing Measures of Bargaining Power." FCND Discussion Paper 86. Food Consumption and Nutrition Division. Washington, DC: International Food Policy Research Institute (IFPRI).

Roy, Sanchari. 2015. "Empowering Women? Inheritance Rights, Female Education and Dowry Payments in India." Journal of Development Economics 114: 233-51.

Sato, Hiroshi, Terry Sicular and Yue Ximing. 2011. "Housing Ownership, Incomes and Inequality in China, 2002-2007." CIBC Working Paper 2011-12, Centre for Human Capital and Productivity (CHCP). London, ON: University of Western Ontario.

Schlager, Edella and Elinor Ostrom. 1992. "Property-Rights Regimes and Natural Resources: A Conceptual Analysis." Land Economics 68(3): 249-62.

Slavchevska, Vanya, Ana Paula de la O Campos, Chiara Brunelli and Cheryl Doss. 2017. "Beyond Ownership: Women's and Men's Land Rights in Sub-Saharan Africa." Paper presented at the 2017 Annual (World) Bank Conference on Africa. Rome: Food and Agriculture Organization of the United Nations (FAO). Retrieved from http://pubdocs.worldbank.org/en/170131495654694482/A2-ABCA-Slavcheska-et-al-2016Beyond-ownership-working-paper.pdf.

Swaminathan, Hema, Rahul Lahoti and Suchitra J. Y. 2012. "Women's Property, Mobility, and Decision-making. Evidence from Rural Karnataka, India." IFPRI Discussion Paper 01188. Poverty, Health and Nutrition Division. Washington, DC: International Food Policy Research Institute (IFPRI).

Thomas, Duncan. 1990. "Intra-Household Resource Allocation: An Inferential Approach." Journal of Human Resources 25(4): 635-64.

Thomas, Duncan. 1997. "Incomes, Expenditures, and Health Outcomes: Evidence on Intrahousehold Resource Allocation.” In: Intrahousehold Resource Allocation in Developing 
Countries: Models, Methods and Policy. by: Lawrence Haddad, John Hoddinott and Harold Alderman (eds.). Baltimore and London: John Hopkins University Press.

World Bank. 2011. World Development Report 2012: Gender Equality and Development. Washington, DC: World Bank.

World Bank. 2015. Women, Business and the Law 2016: Getting to Equal. Washington, DC: World Bank.

World Bank. 2020a. Women, Business and the Law 2020. Washington, DC: World Bank.

World Bank. 2020b. World Development Indicators. Washington, DC: World Bank. Retrieved from http://databank.worldbank.org/data/reports.aspx?source=world-development-indicators (accessed June 20, 2020). 


\section{APPENDIX}

Table A1: Data Definitions

\begin{tabular}{|c|c|c|}
\hline Variable & Definition & Source \\
\hline \multicolumn{3}{|c|}{ Property ownership } \\
\hline $\begin{array}{l}\text { Land ownership } \\
\text { - sole }\end{array}$ & $\begin{array}{l}\text { Indicator variable that equals unity (Yes) if a woman or man reports owning any land either "alone only" or "both } \\
\text { alone and jointly". A value of zero (No) is assigned in all other cases. }\end{array}$ & $\begin{array}{l}\text { DHS } \\
\text { (see Table A2) }\end{array}$ \\
\hline $\begin{array}{l}\text { Land ownership } \\
\text { - sole and joint }\end{array}$ & $\begin{array}{l}\text { Indicator variable that equals unity (Yes) if a woman or man reports owning any land either "alone only", "jointly } \\
\text { only" or "both alone and jointly". A value of zero (No) is assigned in all other cases. }\end{array}$ & \\
\hline $\begin{array}{l}\text { Housing ownership } \\
\text { - sole }\end{array}$ & $\begin{array}{l}\text { Indicator variable that equals unity (Yes) if a woman or man reports owning this or any other house either "alone } \\
\text { only" or "both alone and jointly". A value of zero (No) is assigned in all other cases. }\end{array}$ & \\
\hline $\begin{array}{l}\text { Housing ownership } \\
\text { - sole and joint }\end{array}$ & $\begin{array}{l}\text { Indicator variable that equals unity (Yes) if a woman or man reports owning this or any other house either "alone } \\
\text { only", "jointly only" or "both alone and jointly". A value of zero (No) is assigned in all other cases. }\end{array}$ & \\
\hline $\begin{array}{l}\text { Property ownership } \\
\text { - sole }\end{array}$ & $\begin{array}{l}\text { Indicator variable that equals unity (Yes) if a woman or man reports sole land ownership and/or sole housing } \\
\text { ownership. A value of zero (No) is assigned in all other cases. }\end{array}$ & \\
\hline $\begin{array}{l}\text { Property ownership } \\
\text { - sole and joint }\end{array}$ & $\begin{array}{l}\text { Indicator variable that equals unity (Yes) if a woman or man reports sole or joint land ownership and/or sole or joint } \\
\text { housing ownership. A value of zero (No) is assigned in all other cases. }\end{array}$ & \\
\hline \multicolumn{3}{|c|}{ Legal framework } \\
\hline $\begin{array}{l}\text { Men and women have } \\
\text { equal ownership rights } \\
\text { to immovable property }\end{array}$ & $\begin{array}{l}\text { Indicator variable that equals unity (Yes) if no legal restriction related to property is applied to women or men based } \\
\text { on gender. A value of zero (No) is assigned if legal restrictions on property ownership are applied based on gender, or } \\
\text { if there are gender differences in the legal treatment of spousal property, such as granting the husband administrative } \\
\text { control of marital property. Data in this paper refer to the legal framework in } 2015 \text { (section 4) or } 2020 \text { (section } 2 \text { ). }\end{array}$ & $\begin{array}{l}\text { WBL } \\
\text { (World Bank 2020a) }\end{array}$ \\
\hline $\begin{array}{l}\text { Law provides for the } \\
\text { valuation of non- } \\
\text { monetary } \\
\text { contributions }\end{array}$ & $\begin{array}{l}\text { Indicator variable that equals unity (Yes) if there is an explicit legal recognition of non-monetary contributions (i.e. } \\
\text { caring for children, taking care of the family home, or any other nonmonetized contribution from a stay-at-home } \\
\text { spouse) and the law provides for equal or equitable division of the property or the transfer of a lump sum to the stay- } \\
\text { at-home spouse based on nonmonetary contributions. It also equals unity if the default marital property regime is full, } \\
\text { partial, or deferred community, because these regimes implicitly recognize nonmonetary contributions at the time of } \\
\text { property division and benefit both spouses regardless of who purchased the property or holds title to it. A value of } \\
\text { zero (No) is assigned if the default marital property regime is not full, partial, or deferred community of property, and } \\
\text { there is no explicit legal provision providing for equal or equitable division of property based on nonmonetary } \\
\text { contributions. Data in this paper refer to the legal framework in } 2015 \text { (section 4) or } 2020 \text { (section 2). }\end{array}$ & \\
\hline $\begin{array}{l}\text { Law provides for } \\
\text { equal inheritance } \\
\text { rights of sons and } \\
\text { daughters }\end{array}$ & $\begin{array}{l}\text { Indicator variable that equals unity (Yes) if there are no differences in the rules of intestate succession for transfer of } \\
\text { property from parents to children. A value of zero (No) is assigned if there are gender-based differences in the } \\
\text { recognition of children as heirs to property. Data in this paper refer to the legal framework in } 2020 \text { (section } 2 \text { ). }\end{array}$ & \\
\hline
\end{tabular}




\begin{tabular}{|c|c|c|}
\hline $\begin{array}{l}\text { Law provides for } \\
\text { equal inheritance } \\
\text { rights of male and } \\
\text { female surviving } \\
\text { spouses }\end{array}$ & $\begin{array}{l}\text { Indicator variable that equals unity (Yes) if surviving spouses of either gender have the same inheritance rights. A } \\
\text { value of zero (No) is assigned if there are gender-based differences in the inheritance rights of surviving spouses. Data } \\
\text { in this paper refer to the legal framework in } 2020 \text { (section 2). }\end{array}$ & $\begin{array}{l}\text { WBL } \\
\text { (World Bank 2020a) }\end{array}$ \\
\hline $\begin{array}{l}\text { Law provides for } \\
\text { equal inheritance } \\
\text { rights }\end{array}$ & $\begin{array}{l}\text { Indicator variable that equals unity (Yes) if the law provides for equal inheritance rights of sons and daughters and of } \\
\text { male and female surviving spouses. A value of zero (No) is assigned if there are gender differences in inheritance } \\
\text { rights of children and/or surviving. Data in this paper refer to the legal framework in } 2015 \text { (section } 4 \text { ). }\end{array}$ & \\
\hline $\begin{array}{l}\text { Law mandates equal } \\
\text { remuneration for equal } \\
\text { work }\end{array}$ & $\begin{array}{l}\text { Indicator variable that equals unity (Yes) if employers are legally obliged to pay equal remuneration to male and } \\
\text { female employees who perform work of equal value. A value of zero (No) is assigned if the law limits the principle of } \\
\text { equal remuneration to equal work, the same work, similar work, or work of a similar nature, if the law limits the broad } \\
\text { concept of "remuneration" to only basic wages or salary, or if the law limits the principle of equal remuneration for } \\
\text { work of equal value to the same place of business or same employer. For the purpose of this variable, "remuneration" } \\
\text { refers to the ordinary, basic, or minimum wage or salary and any additional emoluments payable directly or indirectly, } \\
\text { whether in cash or in kind, by the employer to the worker and arising from the worker's employment, while "work of } \\
\text { equal value" refers not only to the same or similar jobs but also to different jobs of the same value. Data in this paper } \\
\text { refer to the legal framework in } 2015 \text { (section 4) or } 2020 \text { (section 2). }\end{array}$ & \\
\hline \multicolumn{3}{|c|}{ Other contemporary country-level variables } \\
\hline $\ln$ GDP pc & Natural log of Gross Domestic Product per capita in 2015 (in constant 2010 U.S. dollars.) & $\begin{array}{l}\text { WDI } \\
\text { (World Bank 2020b) }\end{array}$ \\
\hline Largest religion & $\begin{array}{l}\text { Country's largest religion by proportion. This categorical variable distinguishes between (i) Catholic/Orthodox } \\
\text { Christianity, (ii) Other Christian Denominations; (iii) Islam and (iv) Other (Non-Christian) Religions. }\end{array}$ & $\begin{array}{l}\text { The Association of } \\
\text { Religion Data } \\
\text { Archives } \\
\text { (Harris et al 2019) }\end{array}$ \\
\hline \multicolumn{3}{|c|}{ Historical country-level variables } \\
\hline Absence of inheritance & $\begin{array}{l}\text { Share of a country's ethnic groups for which there is traditionally an absence of inheritance rights of real property (i.e. } \\
\text { land; based on ethnographic data). }\end{array}$ & Alesina et al (2013) \\
\hline Matrilocal societies & $\begin{array}{l}\text { Share of a country's ethnic groups traditionally following matrilocal post-marital residency rules (based on } \\
\text { ethnographic data). }\end{array}$ & \\
\hline Patrilocal societies & $\begin{array}{l}\text { Share of a country's ethnic groups traditionally following patrilocal post-marital residency rules (based on } \\
\text { ethnographic data). }\end{array}$ & \\
\hline Nuclear family & $\begin{array}{l}\text { Share of a country's ethnic groups with a tradition of nuclear family structures (incl. independent monogamous and } \\
\text { polygynous nuclear families; based on ethnographic data). }\end{array}$ & \\
\hline Extended family & $\begin{array}{l}\text { Share of a country's ethnic groups with a tradition of extended family structures (incl. minimal, small and large } \\
\text { extended families; based on ethnographic data). }\end{array}$ & \\
\hline
\end{tabular}


Table A2: List of Demographic and Health Surveys included in this paper

\begin{tabular}{|c|c|c|}
\hline Country & Year & Link \\
\hline Afghanistan & 2015 & https://dhsprogram.com/what-we-do/survey/survey-display-471.cfm \\
\hline Albania & 2017-18 & https://dhsprogram.com/what-we-do/survey/survey-display-525.cfm \\
\hline Armenia & $2015-16$ & https://dhsprogram.com/what-we-do/survey/survey-display-492.cfm \\
\hline Benin & $2017-18$ & https://dhsprogram.com/what-we-do/survey/survey-display-491.cfm \\
\hline Burkina Faso & 2010 & https://dhsprogram.com/what-we-do/survey/survey-display-329.cfm \\
\hline Burundi & $2016-17$ & https://dhsprogram.com/what-we-do/survey/survey-display-463.cfm \\
\hline Chad & $2014-15$ & https://dhsprogram.com/what-we-do/survey/survey-display-465.cfm \\
\hline Colombia & 2015 & https://dhsprogram.com/what-we-do/survey/survey-display-476.cfm \\
\hline Comoros & 2012 & https://dhsprogram.com/what-we-do/survey/survey-display-443.cfm \\
\hline Côte d'Ivoire & $2011-12$ & $\underline{\text { https://dhsprogram.com/what-we-do/survey/survey-display-311.cfm }}$ \\
\hline Congo, Dem. Rep. & 2013-14 & https://dhsprogram.com/what-we-do/survey/survey-display-421.cfm \\
\hline Ethiopia & 2016 & https://dhsprogram.com/what-we-do/survey/survey-display-478.cfm \\
\hline Gambia, The & 2013 & https://dhsprogram.com/what-we-do/survey/survey-display-425.cfm \\
\hline Ghana & 2014 & https://dhsprogram.com/what-we-do/survey/survey-display-437.cfm \\
\hline Guinea & 2018 & https://dhsprogram.com/what-we-do/survey/survey-display-539.cfm \\
\hline Haiti & $2016-17$ & https://dhsprogram.com/what-we-do/survey/survey-display-503.cfm \\
\hline India & $2015-16$ & https://dhsprogram.com/what-we-do/survey/survey-display-355.cfm \\
\hline Indonesia & 2017 & https://dhsprogram.com/what-we-do/survey/survey-display-522.cfm \\
\hline Jordan & $2017-18$ & https://dhsprogram.com/what-we-do/survey/survey-display-500.cfm \\
\hline Kenya & 2014 & https://dhsprogram.com/what-we-do/survey/survey-display-451.cfm \\
\hline Kyrgyz Rep. & 2012 & https://dhsprogram.com/what-we-do/survey/survey-display-383.cfm \\
\hline Lesotho & 2014 & https://dhsprogram.com/what-we-do/survey/survey-display-462.cfm \\
\hline Liberia & 2013 & https://dhsprogram.com/what-we-do/survey/survey-display-435.cfm \\
\hline Malawi & $2015-16$ & https://dhsprogram.com/what-we-do/survey/survey-display-483.cfm \\
\hline Mali & 2018 & $\underline{\text { https://dhsprogram.com/what-we-do/survey/survey-display-517.cfm }}$ \\
\hline Mozambique & 2011 & https://dhsprogram.com/what-we-do/survey/survey-display-362.cfm \\
\hline Myanmar & $2015-16$ & https://dhsprogram.com/what-we-do/survey/survey-display-454.cfm \\
\hline Namibia & 2013 & https://dhsprogram.com/what-we-do/survey/survey-display-363.cfm \\
\hline Nepal & 2016 & https://dhsprogram.com/what-we-do/survey/survey-display-472.cfm \\
\hline Niger & 2012 & https://dhsprogram.com/what-we-do/survey/survey-display-407.cfm \\
\hline Nigeria & 2018 & https://dhsprogram.com/what-we-do/survey/survey-display-528.cfm \\
\hline Rwanda & $2014-15$ & https://dhsprogram.com/what-we-do/survey/survey-display-468.cfm \\
\hline Senegal & 2017 & https://dhsprogram.com/what-we-do/survey/survey-display-534.cfm \\
\hline Sierra Leone & 2013 & https://dhsprogram.com/what-we-do/survey/survey-display-450.cfm \\
\hline South Africa & 2016 & $\underline{\text { https://dhsprogram.com/what-we-do/survey/survey-display-390.cfm }}$ \\
\hline Tanzania & $2015-16$ & https://dhsprogram.com/what-we-do/survey/survey-display-485.cfm \\
\hline Timor-Leste & 2016 & https://dhsprogram.com/what-we-do/survey/survey-display-514.cfm \\
\hline Togo & 2013-14 & https://dhsprogram.com/what-we-do/survey/survey-display-328.cfm \\
\hline Uganda & 2016 & https://dhsprogram.com/what-we-do/survey/survey-display-504.cfm \\
\hline Zambia & 2018 & $\underline{\text { https://dhsprogram.com/what-we-do/survey/survey-display-542.cfm }}$ \\
\hline Zimbabwe & 2015 & https://dhsprogram.com/what-we-do/survey/survey-display-475.cfm \\
\hline
\end{tabular}


Table A3: Male and female ownership of housing and land among married couples

\begin{tabular}{|c|c|c|c|c|c|c|c|c|c|c|c|c|c|c|c|c|c|c|c|c|c|c|c|c|}
\hline \multirow[t]{4}{*}{ Country } & \multicolumn{8}{|c|}{ National } & \multicolumn{8}{|c|}{ Urban } & \multicolumn{8}{|c|}{ Rural } \\
\hline & \multicolumn{4}{|c|}{ Housing } & \multicolumn{4}{|c|}{ Land } & \multicolumn{4}{|c|}{ Housing } & \multicolumn{4}{|c|}{ Land } & \multicolumn{4}{|c|}{ Housing } & \multicolumn{4}{|c|}{ Land } \\
\hline & \multicolumn{2}{|c|}{ Sole } & \multicolumn{2}{|c|}{$\begin{array}{c}\text { Sole and } \\
\text { joint }\end{array}$} & \multicolumn{2}{|c|}{ Sole } & \multicolumn{2}{|c|}{$\begin{array}{c}\text { Sole and } \\
\text { joint }\end{array}$} & \multicolumn{2}{|c|}{ Sole } & \multicolumn{2}{|c|}{$\begin{array}{c}\text { Sole and } \\
\text { joint }\end{array}$} & \multicolumn{2}{|c|}{ Sole } & \multicolumn{2}{|c|}{$\begin{array}{c}\text { Sole and } \\
\text { joint }\end{array}$} & \multicolumn{2}{|c|}{ Sole } & \multicolumn{2}{|c|}{$\begin{array}{c}\text { Sole and } \\
\text { joint }\end{array}$} & \multicolumn{2}{|c|}{ Sole } & & \\
\hline & $\mathbf{F}$ & $\mathbf{M}$ & F & $\mathbf{M}$ & F & $\mathbf{M}$ & F & $\mathbf{M}$ & $\mathbf{F}$ & M & F & $\mathbf{M}$ & $\mathbf{F}$ & M & $\mathbf{F}$ & M & $\mathbf{F}$ & M & $\mathbf{F}$ & M & F & M & $\mathbf{F}$ & $\mathbf{M}$ \\
\hline Afghanistan & 21.0 & 52.0 & 39.8 & 81.8 & 13.1 & 34.6 & 26.6 & 58.5 & 14.6 & 36.1 & 27.9 & 66.3 & 5.3 & 11.9 & 10.0 & 26.2 & 22.5 & 55.8 & 42.6 & 85.4 & 14.9 & 40.0 & 30.5 & 66.2 \\
\hline Albania & 7.4 & 49.8 & 32.6 & 73.3 & 6.8 & 24.4 & 14.7 & 40.1 & 7.9 & 46.3 & 35.1 & 72.7 & 4.2 & 11.3 & 7.5 & 23.1 & 6.7 & 54.6 & 29.4 & 74.0 & 10.1 & 41.6 & 24.2 & 62.5 \\
\hline Armenia & 4.0 & 25.3 & 45.1 & 81.7 & 1.6 & 13.4 & 16.0 & 38.3 & 4.4 & 26.1 & 41.6 & 81.6 & 0.4 & 5.6 & 4.8 & 13.3 & 3.3 & 24.2 & 49.7 & 81.8 & 3.1 & 23.7 & 30.6 & 71.1 \\
\hline $\begin{array}{l}\text { Benin } \\
\text { Burkina }\end{array}$ & 5.2 & 52.5 & 18.6 & 61.1 & 7.7 & 54.0 & 17.5 & 61.1 & 4.6 & 45.4 & 14.6 & 52.6 & 6.2 & 44.6 & 12.3 & 50.1 & 5.6 & 57.1 & 21.2 & 66.6 & 8.6 & 60.2 & 20.9 & 68.3 \\
\hline Faso & 5.3 & 76.8 & 37.6 & 93.8 & 12.8 & 66.3 & 38.8 & 80.9 & 4.1 & 56.3 & 33.7 & 76.1 & 4.6 & 37.7 & 19.9 & 44.4 & 5.5 & 81.4 & 38.5 & 97.8 & 14.6 & 72.8 & 43.1 & 89.2 \\
\hline Burundi & 27.0 & 53.2 & 88.9 & 91.5 & 28.0 & 50.7 & 82.8 & 87.5 & 6.0 & 38.7 & 50.4 & 52.1 & 9.2 & 33.4 & 40.0 & 51.3 & 29.2 & 54.7 & 93.0 & 95.6 & 30.0 & 52.6 & 87.3 & 91.4 \\
\hline Chad & 11.2 & 82.2 & 40.0 & 90.2 & 20.1 & 79.1 & 42.8 & 85.7 & 12.8 & 51.5 & 32.2 & 63.8 & 19.6 & 57.2 & 32.4 & 65.1 & 10.9 & 88.9 & 41.7 & 95.9 & 20.2 & 83.9 & 45.1 & 90.1 \\
\hline Colombia & 9.1 & 10.8 & 37.4 & 41.1 & 5.9 & 8.4 & 15.3 & 20.8 & 9.6 & 10.3 & 33.9 & 36.6 & 5.2 & 6.0 & 10.7 & 14.2 & 7.8 & 12.0 & 45.9 & 52.1 & 7.7 & 14.4 & 26.5 & 37.0 \\
\hline Comoros & 70.0 & 26.1 & 85.2 & 71.3 & 55.3 & 26.9 & 71.9 & 66.4 & 59.0 & 23.3 & 79.6 & 64.3 & 50.3 & 21.7 & 68.1 & 54.6 & 75.0 & 27.4 & 87.7 & 74.5 & 57.7 & 29.3 & 73.7 & 71.9 \\
\hline $\begin{array}{l}\text { Côte } \\
\text { Cong }\end{array}$ & 9.7 & 53.6 & 43.1 & 63.0 & 10.0 & 54.2 & 39.4 & 64.5 & 6.4 & 22.1 & 23.3 & 28.4 & 4.7 & 24.3 & 17.0 & 33.3 & 11.5 & 70.9 & 54.0 & 82.0 & 12.8 & 70.6 & 51.6 & 81.6 \\
\hline & 13.7 & 47.7 & 53.6 & 71.8 & 13.5 & 36.2 & 47.6 & 63.8 & 8.5 & 29.5 & 29.6 & 45.7 & 8.3 & 21.2 & 24.2 & 35.2 & 15.7 & 55.0 & 63.2 & 82.2 & 15.5 & 42.2 & 56.8 & 75.1 \\
\hline Ethiopia & 17.9 & 58.6 & 69.1 & 86.9 & 19.3 & 55.0 & 55.7 & 79.1 & 7.2 & 34.3 & 44.1 & 54.6 & 5 & 19.6 & 21.5 & 30.9 & 19.6 & 62.6 & 73.2 & 92.2 & 21.7 & 60.8 & 61.3 & 87.0 \\
\hline Gambia, The & 7.5 & 41.9 & 24.1 & 61.4 & 6.1 & 37.3 & 19.2 & 50.8 & 5.7 & 24.2 & 18.8 & 41.7 & 6.9 & 34.6 & 18.0 & 47.4 & 9.0 & 57.4 & 28.8 & 78.6 & 5.3 & 39.6 & 20.1 & 53.8 \\
\hline Ghana & 9.7 & 38.6 & 27.0 & 45.8 & 14.7 & 47.1 & 31.8 & 58.3 & 8.2 & 24.0 & 20.0 & 28.7 & 14.0 & 43.9 & 30.9 & 50.9 & 11.2 & 51.6 & 33.3 & 61.1 & 15.4 & 50.0 & 32.5 & 64.9 \\
\hline Guinea & 14.1 & 65.3 & 45.4 & 76.9 & 15.9 & 57.0 & 39.5 & 67.1 & 9.6 & 40.8 & 26.4 & 48.0 & 3.7 & 18.7 & 11.5 & 22.9 & 16.0 & 75.2 & 53.1 & 88.5 & 20.9 & 72.5 & 50.8 & 84.9 \\
\hline Haiti & 10.0 & 26.3 & 53.1 & 60.3 & 14.4 & 36.1 & 48.9 & 61.4 & 7.7 & 18.5 & 36.0 & 43.0 & 12.8 & 24.6 & 31.5 & 42.7 & 11.4 & 31.3 & 64.0 & 71.3 & 15.5 & 43.5 & 60.0 & 73.3 \\
\hline India & 22.5 & 65.9 & 39.0 & 79.1 & 16.6 & 46.0 & 29.7 & 58.7 & 20.7 & 60.4 & 35.7 & 72.7 & 13.2 & 33.9 & 23.9 & 44.4 & 23.4 & 68.8 & 40.8 & 82.6 & 18.4 & 52.5 & 32.8 & 66.4 \\
\hline Indonesia & 24.6 & 49.9 & 65.4 & 69.9 & 17.4 & 38.5 & 38.0 & 50.0 & 24.7 & 46.6 & 59.4 & 64.5 & 13.9 & 32.0 & 27.8 & 40.6 & 24.6 & 53.0 & 71.1 & 75.0 & 20.8 & 44.5 & 47.6 & 58.8 \\
\hline Jordan & 7.4 & 53.9 & 10.1 & 56.0 & 3.7 & 21.2 & 7.1 & 24.3 & 7.2 & 50.9 & 9.9 & 53.1 & & 18.6 & 6.7 & 21.4 & 10.0 & 80.8 & 12.4 & 82.5 & 5.4 & 44.4 & 10.2 & 49.7 \\
\hline Kenya & 11.0 & 57.3 & 61.4 & 76.9 & 9.6 & 50.9 & 55.9 & 73.5 & 7.6 & 40.7 & 38.3 & 53.1 & 7.1 & 44.2 & 36.8 & 61.1 & 13.3 & 68.4 & 76.8 & 92.7 & 11.3 & 55.5 & 68.7 & 81.8 \\
\hline Kyrgyz Rep. & 25.4 & 52.7 & 68.9 & 85.7 & 18.1 & 32.2 & 42.7 & 58.3 & 22.5 & 45.5 & 61.0 & 75.4 & 10.9 & 18.2 & 22.1 & 28.3 & 26.8 & 56.3 & 72.7 & 90.7 & 21.5 & 39.0 & 52.7 & 72.7 \\
\hline Lesotho & 6.9 & 11.5 & 56.6 & 60.1 & 4.7 & 11.6 & 43.4 & 49.4 & 4.8 & 11.9 & 49.0 & 50.5 & 5.6 & 14.1 & 48.1 & 54.7 & 8.0 & 11.3 & 60.7 & 65.3 & 4.2 & 10.2 & 40.9 & 46.5 \\
\hline Liberia & 12.4 & 30.1 & 42.3 & 44.8 & n.a. & n.a. & n.a. & n.a. & 9.6 & 19.6 & 30.1 & 30.2 & n.a. & n.a. & n.a. & n.a. & 15.5 & 41.7 & 55.7 & 60.9 & n.a. & n.a. & n.a. & n.a. \\
\hline Malawi & 43.2 & 67.7 & 76.5 & 79.4 & 45.8 & 66.1 & 75.5 & 76.9 & 24.5 & 29.7 & 41.0 & 40.4 & 23.7 & 31.0 & 37.6 & 38.8 & 46.4 & 74.3 & 82.7 & 86.2 & 49.6 & 72.2 & 82.1 & 83.5 \\
\hline Mali & 7.3 & 50.7 & 36.5 & 71.8 & 17.7 & 42.9 & 38.2 & 63.1 & 8.4 & 21.5 & 24.1 & 38.9 & 3.4 & 8.3 & 10.5 & 17.8 & 7.0 & 58.7 & 39.9 & 80.7 & 21.6 & 52.3 & 45.7 & 75.4 \\
\hline Mozambique & 12.1 & 52.4 & 82.1 & 87.9 & 11.3 & 43.2 & 68.6 & 80.0 & 8.6 & 52.7 & 73.2 & 76.2 & 7.9 & 33.0 & 54.4 & 51.4 & 13.5 & 52.3 & 85.9 & 92.8 & 12.8 & 47.5 & 74.6 & 91.9 \\
\hline Myanmar & 37.5 & 50.4 & 66.7 & 69.4 & 32.0 & 41.7 & 59.7 & 59.3 & 27.9 & 34.0 & 52.2 & 53.5 & 23.4 & 29.3 & 46.4 & 47.1 & 40.8 & 56.0 & 71.6 & 74.8 & 34.9 & 45.9 & 64.2 & 63.4 \\
\hline Namibia & 30.4 & 38.6 & 56.4 & 61.0 & 19.5 & 28.0 & 37.6 & 41.4 & 29.2 & 35.9 & 56.1 & 59.9 & 16.0 & 24.8 & 32.1 & 38.5 & 32.5 & 43.1 & 56.8 & 62.9 & 25.1 & 33.2 & 46.7 & 46.2 \\
\hline
\end{tabular}


Table A3: Male and female ownership of housing and land among married couples (continued)

\begin{tabular}{|c|c|c|c|c|c|c|c|c|c|c|c|c|c|c|c|c|c|c|c|c|c|c|c|c|}
\hline \multirow[t]{4}{*}{ Country } & \multicolumn{8}{|c|}{ National } & \multicolumn{8}{|c|}{ Urban } & \multicolumn{8}{|c|}{ Rural } \\
\hline & \multicolumn{4}{|c|}{ Housing } & \multicolumn{4}{|c|}{ Land } & \multicolumn{4}{|c|}{ Housing } & \multicolumn{4}{|c|}{ Land } & \multicolumn{4}{|c|}{ Housing } & \multicolumn{4}{|c|}{ Land } \\
\hline & \multicolumn{2}{|c|}{ Sole } & \multicolumn{2}{|c|}{$\begin{array}{c}\text { Sole and } \\
\text { joint }\end{array}$} & \multicolumn{2}{|c|}{ Sole } & \multicolumn{2}{|c|}{$\begin{array}{l}\text { Sole and } \\
\text { joint }\end{array}$} & \multicolumn{2}{|c|}{ Sole } & \multicolumn{2}{|c|}{$\begin{array}{l}\text { Sole and } \\
\text { joint }\end{array}$} & \multicolumn{2}{|c|}{ Sole } & \multicolumn{2}{|c|}{$\begin{array}{c}\text { Sole and } \\
\text { joint }\end{array}$} & \multicolumn{2}{|c|}{ Sole } & \multicolumn{2}{|c|}{$\begin{array}{c}\text { Sole and } \\
\text { joint }\end{array}$} & \multicolumn{2}{|c|}{ Sole } & \multicolumn{2}{|c|}{$\begin{array}{l}\text { Sole and } \\
\text { joint }\end{array}$} \\
\hline & $\mathbf{F}$ & M & $\mathbf{F}$ & M & F & $\mathbf{M}$ & $\mathbf{F}$ & M & F & $\mathbf{M}$ & $\mathbf{F}$ & M & $\mathbf{F}$ & M & F & M & F & $\mathbf{M}$ & $\mathbf{F}$ & $\mathbf{M}$ & $\mathbf{F}$ & M & $\mathbf{F}$ & M \\
\hline Nepal & 6.5 & 27.8 & 7.5 & 29.2 & 10.8 & 29.9 & 12.3 & 31.4 & 7.4 & 26.0 & 8.8 & 27.9 & 12.0 & 29.2 & 14.3 & 31.3 & 5.1 & 30.8 & 5.2 & 31.4 & 8.8 & 31.0 & 9.0 & 31.5 \\
\hline Niger & 19.3 & 82.7 & 41.0 & 91.7 & 26.1 & 59.0 & 39.8 & 67.7 & 13.4 & 51.3 & 27.4 & 59.8 & 13.4 & 35.3 & 22.7 & 43.1 & 20.2 & 88.0 & 43.3 & 97.1 & 28.2 & 63.0 & 42.7 & 71.8 \\
\hline Nigeria & 4.0 & 43.9 & 12.1 & 62.1 & 5.7 & 47.7 & 13.9 & 62.3 & 4.4 & 29.0 & 14.8 & 42.3 & 3.9 & 28.5 & 14.6 & 39.2 & 3.8 & 55.0 & 10.2 & 76.8 & 7.0 & 61.9 & 13.3 & 79.5 \\
\hline Rwanda & 5.1 & 34.4 & 80.0 & 84.7 & 6.0 & 28.7 & 70.9 & 77.7 & 3.7 & 26.4 & 53.7 & 59.6 & 6.1 & 23.3 & 42.0 & 49.3 & 5.4 & 35.9 & 85.1 & 89.6 & 6.0 & 29.7 & 76.6 & 83.2 \\
\hline $\begin{array}{l}\text { Senegal } \\
\text { Sierra }\end{array}$ & 1.5 & 31.7 & 8.0 & 52.4 & 4.2 & 43.6 & 7.2 & 52.7 & 2.4 & 21.6 & 7.7 & 34.4 & 4.0 & 25.9 & 6.2 & 29.8 & 0.9 & 38.7 & 8.2 & 65.0 & 4.4 & 56.1 & 7.8 & 68.7 \\
\hline $\begin{array}{l}\text { Leone } \\
\text { South }\end{array}$ & 11.3 & 44.2 & 52.6 & 63.4 & 9.5 & 41.1 & 48.6 & 58.9 & 7.4 & 22.5 & 28.4 & 32.4 & 6.9 & 23.8 & 29.2 & 34.8 & 12.5 & 51.2 & 60.5 & 73.6 & 10.3 & 46.8 & 54.9 & 66.8 \\
\hline Africa & 27.2 & 28.4 & 48.9 & 47.7 & n.a. & n.a. & n.a. & n.a. & 26.2 & 25.2 & 46.4 & 41.5 & n.a. & n.a. & n.a. & n.a. & 29.9 & 37.4 & 56.1 & 64.9 & n.a. & n.a. & n.a. & n.a. \\
\hline $\begin{array}{l}\text { Tanzania } \\
\text { Timor- }\end{array}$ & 7.0 & 57.9 & 51.3 & 71.6 & 7.6 & 48.1 & 46.8 & 61.5 & 7.7 & 36.4 & 35.5 & 49.2 & 8.0 & 30.4 & 26.9 & 40.4 & 6.7 & 67.4 & 58.2 & 81.5 & 7.4 & 56.0 & 55.6 & 70.9 \\
\hline Leste & 55.7 & 70.0 & 94.8 & 96.4 & 47.8 & 56.9 & 80.7 & 80.9 & 59.7 & 77.0 & 91.5 & 92.5 & 33.1 & 34.2 & 50.5 & 43.0 & 54.3 & 67.5 & 95.9 & 97.8 & 52.9 & 64.9 & 91.3 & 94.2 \\
\hline Togo & 5.9 & 51.4 & 14.7 & 55.6 & 7.3 & 49.9 & 12.9 & 54.1 & 5.6 & 27.9 & 9.3 & 30.7 & 7.2 & 34.9 & 11.1 & 39.6 & 6.1 & 63.9 & 17.5 & 68.8 & 7.4 & 57.9 & 13.9 & 61.7 \\
\hline Uganda & 7.4 & 63.2 & 57.9 & 83.1 & 7.8 & 56.7 & 44.2 & 74.5 & 7.3 & 47.6 & 39.3 & 61.7 & 8.6 & 46.1 & 34.2 & 60.6 & 7.4 & 67.2 & 62.8 & 88.7 & 7.6 & 59.4 & 46.8 & 78.2 \\
\hline Zambia & 12.4 & 41.4 & 53.0 & 68.9 & 7.5 & 35.8 & 41.1 & 58.7 & 13.3 & 26.7 & 31.5 & 36.8 & 4.7 & 14.1 & 13.9 & 21.3 & 11.9 & 50.0 & 65.5 & 87.6 & 9.1 & 48.5 & 57.0 & 80.5 \\
\hline Zimbabwe & 6.3 & 24.6 & 53.2 & 64.8 & 4.7 & 23.5 & 44.0 & 58.7 & 7.5 & 18.1 & 37.5 & 41.1 & 5.1 & 15.9 & 23.3 & 36.2 & 5.6 & 27.9 & 61.2 & 77.0 & 4.5 & 27.4 & 54.7 & 70.3 \\
\hline
\end{tabular}




\begin{tabular}{|c|c|c|c|c|}
\hline & \multicolumn{2}{|c|}{ Urban } & \multicolumn{2}{|c|}{ Rural } \\
\hline & mean & se & mean & se \\
\hline \multicolumn{5}{|l|}{ Dependent variables: } \\
\hline Wife's land ownership & 0.235 & $(0.018)$ & 0.433 & $(0.035)$ \\
\hline Wife's house ownership & 0.364 & $(0.023)$ & 0.509 & $(0.036)$ \\
\hline \multicolumn{5}{|l|}{ Legal framework of the country: } \\
\hline Men and women have equal ownership rights to immovable property & 0.942 & $(0.032)$ & 0.919 & $(0.046)$ \\
\hline Law provides for the valuation of non-monetary contributions & 0.414 & $(0.150)$ & 0.329 & $(0.128)$ \\
\hline Law provides for equal inheritance rights & 0.727 & $(0.114)$ & 0.721 & $(0.132)$ \\
\hline Law mandates equal remuneration for equal work & 0.148 & $(0.063)$ & 0.178 & $(0.077)$ \\
\hline \multicolumn{5}{|l|}{ Other country-level controls: } \\
\hline ln GDP pc (2015, in 2010 constant USD) & 7.416 & $(0.220)$ & 7.057 & $(0.187)$ \\
\hline \multicolumn{5}{|l|}{ Largest religion by proportion } \\
\hline Catholic or Orthodox & 0.236 & $(0.123)$ & 0.166 & $(0.076)$ \\
\hline Other Christian & 0.116 & $(0.056)$ & 0.117 & $(0.059)$ \\
\hline Muslim & 0.338 & $(0.128)$ & 0.367 & $(0.151)$ \\
\hline Other & 0.311 & $(0.198)$ & 0.350 & $(0.217)$ \\
\hline Absence of inheritance & 0.082 & $(0.039)$ & 0.052 & $(0.023)$ \\
\hline Matrilocal societies & 0.044 & $(0.021)$ & 0.038 & $(0.021)$ \\
\hline Patrilocal societies & 0.748 & $(0.091)$ & 0.816 & $(0.058)$ \\
\hline Nuclear family & 0.217 & $(0.060)$ & 0.151 & $(0.035)$ \\
\hline Extended family & 0.581 & $(0.069)$ & 0.606 & $(0.074)$ \\
\hline \multicolumn{5}{|l|}{ World region } \\
\hline East Asia \& Pacific & 0.080 & $(0.065)$ & 0.055 & $(0.040)$ \\
\hline Europe \& Central Asia & 0.034 & $(0.024)$ & 0.023 & $(0.016)$ \\
\hline Latin America \& Caribbean & 0.137 & $(0.116)$ & 0.046 & $(0.037)$ \\
\hline Middle East \& North Africa & 0.031 & $(0.032)$ & 0.004 & $(0.004)$ \\
\hline South Asia & 0.355 & $(0.191)$ & 0.440 & $(0.198)$ \\
\hline Sub-Saharan Africa & 0.362 & $(0.127)$ & 0.432 & $(0.159)$ \\
\hline \multicolumn{5}{|l|}{ Characteristics of the wife: } \\
\hline Wife's total number of sons ever born & 1.406 & $(0.096)$ & 1.779 & $(0.144)$ \\
\hline Wife's total number of daughters ever born & 1.319 & $(0.094)$ & 1.673 & $(0.137)$ \\
\hline Wife's age in years & 32.498 & $(0.424)$ & 31.610 & $(0.445)$ \\
\hline \multicolumn{5}{|l|}{ Wife's education } \\
\hline No education & 0.210 & $(0.047)$ & 0.469 & $(0.066)$ \\
\hline 1 to 4 years of education & 0.065 & $(0.007)$ & 0.107 & $(0.018)$ \\
\hline 5 to 8 years of education & 0.224 & $(0.014)$ & 0.233 & $(0.029)$ \\
\hline 9 to 12 years of education & 0.337 & $(0.030)$ & 0.155 & $(0.032)$ \\
\hline 13 or more years of education & 0.164 & $(0.019)$ & 0.036 & $(0.008)$ \\
\hline \multicolumn{5}{|l|}{ Wife's type of work } \\
\hline Not working & 0.465 & $(0.102)$ & 0.472 & $(0.078)$ \\
\hline Services & 0.378 & $(0.096)$ & 0.149 & $(0.037)$ \\
\hline Agriculture & 0.063 & $(0.014)$ & 0.301 & $(0.044)$ \\
\hline Industry/manual & 0.077 & $(0.009)$ & 0.060 & $(0.007)$ \\
\hline $\mathrm{DK} /$ missing/other & 0.017 & $(0.009)$ & 0.018 & $(0.011)$ \\
\hline \multicolumn{5}{|l|}{ Characteristics of the husband: } \\
\hline Husband's total number of sons ever born & 1.602 & $(0.153)$ & 2.155 & $(0.269)$ \\
\hline Husband's total number of daughters ever born & 1.485 & $(0.148)$ & 2.003 & $(0.262)$ \\
\hline Husband's age in years & 38.040 & $(0.340)$ & 37.262 & $(0.460)$ \\
\hline \multicolumn{5}{|l|}{ Husband's education } \\
\hline No education & 0.132 & $(0.027)$ & 0.323 & $(0.054)$ \\
\hline 1 to 4 years of education & 0.069 & $(0.007)$ & 0.118 & $(0.015)$ \\
\hline 5 to 8 years of education & 0.228 & $(0.011)$ & 0.266 & $(0.023)$ \\
\hline 9 to 12 years of education & 0.361 & $(0.023)$ & 0.229 & $(0.037)$ \\
\hline
\end{tabular}


Table A4: Descriptive statistics (continued)

\begin{tabular}{lcccc}
\hline 13 or more years of education & 0.210 & $(0.013)$ & 0.064 & $(0.010)$ \\
Husband's type of work & & & & \\
$\quad$ Not working & 0.046 & $(0.012)$ & 0.038 & $(0.008)$ \\
$\quad$ Services & 0.505 & $(0.024)$ & 0.197 & $(0.014)$ \\
$\quad$ Agriculture & 0.112 & $(0.013)$ & 0.546 & $(0.033)$ \\
$\quad$ Industry/manual & 0.325 & $(0.016)$ & 0.212 & $(0.023)$ \\
$\quad$ DK/missing/other & 0.011 & $(0.004)$ & 0.006 & $(0.003)$ \\
Characteristics of the couple: & & & & \\
Both spouses are working & 0.499 & $(0.102)$ & 0.496 & $(0.073)$ \\
Husband-wife education gap & 1.044 & $(0.275)$ & 1.475 & $(0.252)$ \\
Household headship & & & & \\
$\quad$ Husband head of household & 0.786 & $(0.028)$ & 0.786 & $(0.038)$ \\
$\quad$ Wife head of household & 0.033 & $(0.013)$ & 0.017 & $(0.005)$ \\
$\quad$ Other male household head & 0.134 & $(0.031)$ & 0.166 & $(0.039)$ \\
$\quad$ Other female household head & 0.046 & $(0.007)$ & 0.031 & $(0.007)$ \\
\hline N & \multicolumn{2}{c}{70,088} & & 140,754 \\
\hline
\end{tabular}

Note: Data for 39 countries from 2010-18 (only includes observations with non-missing data on all variables). Standard errors clustered at the country level. Source: DHS. 
Table A5: Marginal effects (multinomial logit estimation)

\begin{tabular}{|c|c|c|c|c|c|c|}
\hline & \multicolumn{3}{|c|}{ Urban } & \multicolumn{3}{|c|}{ Rural } \\
\hline & (1) & $(2)$ & $(3)$ & $(1)$ & (2) & (3) \\
\hline \multicolumn{7}{|c|}{ Housing ownership } \\
\hline \multicolumn{7}{|c|}{ Outcome 0: No one among the couple owns } \\
\hline Men and women have equal ownership rights to & -0.051 & -0.094 & $-0.145^{* *}$ & 0.007 & -0.031 & -0.048 \\
\hline immovable property & $(-0.81)$ & $(-1.28)$ & $(-2.03)$ & $(0.14)$ & $(-0.55)$ & $(-1.02)$ \\
\hline Law provides for the valuation of non- & $-0.103^{* *}$ & $-0.109^{* *}$ & $-0.117^{* *}$ & $-0.075^{* *}$ & $-0.092^{* * *}$ & $-0.084^{* * *}$ \\
\hline monetary contributions & $(-2.38)$ & $(-2.23)$ & $(-2.39)$ & $(-2.56)$ & $(-3.01)$ & $(-3.02)$ \\
\hline Law provides for equal inheritance rights & -0.076 & -0.112 & -0.102 & -0.033 & -0.050 & -0.029 \\
\hline & $(-1.36)$ & $(-1.32)$ & $(-1.20)$ & $(-1.27)$ & $(-0.90)$ & $(-0.51)$ \\
\hline Law mandates equal remuneration for equal & $-0.092^{* *}$ & $-0.131^{* *}$ & $-0.124^{* *}$ & -0.022 & -0.050 & -0.035 \\
\hline work & $(-2.41)$ & $(-2.16)$ & $(-2.12)$ & $(-0.63)$ & $(-1.06)$ & $(-0.82)$ \\
\hline \multicolumn{7}{|c|}{ Outcome 1: Only the husband owns either alone or jointly with others (but not the wife) } \\
\hline Men and women have equal ownership rights to & $-0.111^{*}$ & -0.073 & -0.042 & $-0.219^{* * *}$ & $-0.172^{* * *}$ & $-0.154^{* *}$ \\
\hline immovable property & $(-1.78)$ & $(-1.14)$ & $(-0.65)$ & $(-2.67)$ & $(-2.75)$ & $(-2.52)$ \\
\hline Law provides for the valuation of non- & -0.069 & -0.003 & 0.010 & $-0.127^{*}$ & -0.047 & -0.039 \\
\hline monetary contributions & $(-1.24)$ & $(-0.05)$ & $(0.19)$ & $(-1.70)$ & $(-0.84)$ & $(-0.78)$ \\
\hline Law provides for equal inheritance rights & -0.012 & 0.018 & 0.009 & -0.059 & -0.007 & -0.026 \\
\hline & $(-0.33)$ & $(0.44)$ & $(0.21)$ & $(-1.18)$ & $(-0.13)$ & $(-0.53)$ \\
\hline Law mandates equal remuneration for equal & -0.011 & 0.043 & 0.030 & -0.100 & -0.009 & -0.029 \\
\hline work & $(-0.24)$ & $(1.31)$ & $(0.94)$ & $(-1.30)$ & $(-0.19)$ & $(-0.60)$ \\
\hline \multicolumn{7}{|c|}{ Outcome 2: Wife owns the house alone or jointly with husband or others } \\
\hline Men and women have equal ownership rights to & $0.163^{* * *}$ & $0.167^{* * *}$ & $0.186^{* * *}$ & $0.212^{* * *}$ & $0.202^{* * *}$ & $0.203^{* * *}$ \\
\hline $\begin{array}{l}1 \mathrm{mmovab} \text { le property } \\
\text { Law provides for the valuation of non- }\end{array}$ & $(3.13)$ (172** & $\begin{array}{l}(2.93) \\
0.112^{* *}\end{array}$ & $\begin{array}{l}(3.25) \\
0.107^{* *}\end{array}$ & $\begin{array}{c}(2.93) \\
0.201^{* * *}\end{array}$ & $0.139^{* * *}$ & $(2.74)$ \\
\hline monetary contributions & $(3.77)$ & $(2.51)$ & $(2.41)$ & $(2.81)$ & $(2.92)$ & $(2.68)$ \\
\hline Law provides for equal inheritance rights & $0.088^{*}$ & 0.094 & 0.093 & 0.092 & 0.057 & 0.055 \\
\hline & $(1.67)$ & $(1.17)$ & $(1.20)$ & $(1.51)$ & $(0.69)$ & $(0.68)$ \\
\hline Law mandates equal remuneration for equal & $0.103^{*}$ & 0.088 & 0.094 & 0.123 & 0.059 & 0.064 \\
\hline work & $(1.87)$ & $(1.42)$ & $(1.56)$ & $(1.24)$ & $(0.74)$ & $(0.84)$ \\
\hline \multicolumn{7}{|c|}{ Land ownership } \\
\hline \multicolumn{7}{|c|}{ Outcome 0: No one among the couple owns } \\
\hline Men and women have equal ownership rights to & -0.031 & -0.000 & -0.055 & 0.012 & 0.006 & -0.020 \\
\hline immovable property & $(-0.44)$ & $(-0.00)$ & $(-0.67)$ & $(0.29)$ & $(0.11)$ & $(-0.40)$ \\
\hline Law provides for the valuation of non- & $-0.089^{*}$ & $-0.112^{* *}$ & $-0.115^{* *}$ & -0.046 & $-0.058^{*}$ & -0.041 \\
\hline monetary contributions & $(-1.76)$ & $(-2.35)$ & $(-2.52)$ & $(-1.51)$ & $(-1.74)$ & $(-1.31)$ \\
\hline Law provides for equal inheritance rights & $-0.078^{*}$ & -0.014 & -0.015 & $-0.063^{* *}$ & -0.076 & -0.056 \\
\hline & $(-1.91)$ & $(-0.23)$ & $(-0.21)$ & $(-2.40)$ & $(-1.37)$ & $(-1.00)$ \\
\hline Law mandates equal remuneration for equal & $-0.161^{* * *}$ & $-0.141^{* *}$ & $-0.149^{* *}$ & -0.030 & -0.043 & -0.033 \\
\hline work & $(-4.02)$ & $(-2.37)$ & $(-2.54)$ & $(-0.77)$ & $(-0.77)$ & $(-0.63)$ \\
\hline \multicolumn{7}{|c|}{ Outcome 1: Only the husband owns either alone or jointly with others (but not the wife) } \\
\hline Men and women have equal ownership rights to & -0.056 & -0.047 & -0.016 & $-0.164^{* * *}$ & $-0.117^{* * *}$ & $-0.099^{* * *}$ \\
\hline immovable property & $(-1.43)$ & $(-0.90)$ & $(-0.33)$ & $(-2.77)$ & $(-3.04)$ & $(-2.66)$ \\
\hline Law provides for the valuation of non- & -0.019 & 0.029 & 0.038 & $-0.116^{* *}$ & -0.040 & -0.034 \\
\hline monetary contributions & $(-0.59)$ & $(0.87)$ & $(1.22)$ & $(-2.17)$ & $(-1.07)$ & $(-1.00)$ \\
\hline Law provides for equal inheritance rights & 0.001 & 0.005 & -0.004 & -0.051 & -0.008 & -0.028 \\
\hline & $(0.03)$ & $(0.18)$ & $(-0.13)$ & $(-1.24)$ & $(-0.19)$ & $(-0.71)$ \\
\hline Law mandates equal remuneration for equal & 0.048 & $0.076^{* * *}$ & $0.069^{* *}$ & -0.091 & -0.000 & -0.019 \\
\hline work & $(1.54)$ & $(3.01)$ & $(2.56)$ & $(-1.34)$ & $(-0.01)$ & $(-0.47)$ \\
\hline \multicolumn{7}{|c|}{ Outcome 2: Wife owns the house alone or jointly with husband or others } \\
\hline Men and women have equal ownership rights to & 0.087 & 0.047 & 0.072 & $0.152^{* *}$ & $0.111^{*}$ & $0.119^{*}$ \\
\hline immovable property & $(1.64)$ & $(0.86)$ & $(1.37)$ & $(2.39)$ & $(1.66)$ & $(1.78)$ \\
\hline Law provides for the valuation of non- & $0.108^{* * *}$ & $0.083^{* *}$ & $0.078^{* *}$ & $0.163^{* * *}$ & $0.099^{* *}$ & $0.074^{*}$ \\
\hline monetary contributions & $(2.59)$ & $(2.18)$ & $(1.97)$ & $(2.79)$ & $(2.42)$ & $(1.75)$ \\
\hline Law provides for equal inheritance rights & $0.078^{* *}$ & 0.009 & 0.018 & $0.114^{* *}$ & 0.084 & 0.083 \\
\hline & $(2.01)$ & $(0.16)$ & $(0.31)$ & $(2.08)$ & $(1.25)$ & $(1.23)$ \\
\hline Law mandates equal remuneration for equal & $0.113^{* *}$ & 0.065 & $0.081^{*}$ & 0.121 & 0.044 & 0.051 \\
\hline work & $(2.56)$ & $(1.30)$ & $(1.65)$ & $(1.33)$ & $(0.59)$ & $(0.71)$ \\
\hline
\end{tabular}

